\title{
Early Jurassic brachiopods from diverse localities of northern Anatolia (Turkey)
}

\author{
A. VöRös \\ Department of Palaeontology and Geology, Hungarian Natural History Museum \\ H-1083 Budapest, Ludovika tér 2, Hungary.E-mail:voros@nhmus.hu
}

\begin{abstract}
The Early Jurassic brachiopods collected by Füsun Alkaya from diverse localities of northern Anatolia (Turkey) were examined in detail. The taxonomic and nomenclatural study of the 93 specimens resulted in 32 brachiopod taxa. They represent 18 genera and 31 nominal species; these are shortly described and documented by photographs and partly by serial sections. The species Cirpa alkayae is introduced and described as new. The brachiopod localities fall to the Sakarya Zone of northern Anatolia. Presence vs. absence data of the identified species in the major Tethyan palaeogeographic provinces show that the Early Jurassic brachiopod fauna of the Sakarya Zone has a transitional character between the two major faunal provinces (NW-European and Mediterranean). With 115 figures and 1 table.
\end{abstract}

Key words - Brachiopoda, Lower Jurassic, systematic description, Turkey

\section{INTRODUCTION}

The present work was initiated by Dr Hayriye Füsun Alkaya (at the Ankara University at that time), who made a short visit at the Department of Palaeontology of the Eötvös Loránd University, Budapest in 1986. Dr Alkaya worked hard on Early Jurassic ammonoids of Turkey (ALKAYA 1981, 1982, 1983, 1984, 1991) and collected many brachiopods besides the ammonoids. During the personal talks and a detailed letter in 1991, she encouraged the present author to work on this brachiopod material and in 1992 she mailed a box of Jurassic brachiopods to the Hungarian Natural History Museum. Afterwards, the fossil collection of the Department of Palaeontology and Geology had to move three times, partly to different buildings of Budapest which resulted some degree of disorder. For a long time, the parcel with brachiopods has been appeared to be lost. But recently, it was found again and the carefully packed and labelled brachiopods reached their safe place in due order.

Previous and recent publications on the Early Jurassic brachiopods from Turkey contained mostly faunal lists with few or no illustrations (VADÁsz 1913a, 
b, 1918; OtKUn 1942; AgER et al. 1980; AgER 1991) or described brachiopod faunas from single localities, where the stratigraphic position was uncertain or was based solely on brachiopod evidence (AGER 1959a; Vörös \& KANDEMIR 2011; VÖRÖs 2014).

The Early Jurassic brachiopods collected by Füsun Alkaya have particular significance in the knowledge of the Turkish faunas, because: (1) the material came from an extensive area (10 localities) of northern Anatolia and, (2) in most cases, the brachiopods have been collected by Füsun Alkaya together with agediagnostic ammonoids. These make reasonable to publish the detailed palaeontological description of this well-dated and well-preserved brachiopod fauna.

In those times when Dr Füsun Alkaya sent the brachiopods to the present author, she promised to provide detailed information on the stratigraphy of the localities and the idea was to prepare a joint publication. In the last years the author made multiple attempts (via e-mails and Facebook; correspondence with Turkish colleagues and former co-authors) to contact Dr Füsun Alkaya, but the efforts failed. Due to this regrettable situation, this paper remained as singleauthored and the merits of Dr Füsun Alkaya are celebrated only by a new species nominated after her name.

\section{MATERIAL AND LOCALITIES}

The Early Jurassic brachiopod material ( 93 specimens) sent by F. Alkaya has been collected from 10 localities of northern Anatolia; in some cases from different stratigraphic levels of the measured sections (Fig. 1). The specimen numbers of the respective brachiopod taxa according to localities are shown in Table 1. Concise information about the brachiopod-bearing stratigraphical successions and the geographical and geological setting of the localities (partly given by $\mathrm{F}$. Alkaya) are listed below.

\section{Bilecik area, Günüviran}

This locality lies about $20 \mathrm{~km}$ to the north of the town Bilecik. The lithology and ammonoid stratigraphy of the section was described and illustrated by AlKaYA (1981), who also gave a list of nine brachiopod species from here. The locality Günüviran is probably identical with that mentioned as Günören by ALTINER et al. (1991), who published further details on its stratigraphy, and as Gunoren by AGER (1991, p. 240), who listed 15 brachiopod species from the upper Sinemurian to lower Pliensbachian beds. In the presently described material from Günüviran, eight brachiopods, collected by F. Alkaya as loose from the upper Sinemurian to Carixian red limestone and marl, represent Linguithyris 
aspasia (Zittel), Aulacothyris resupinata (J. Sowerby) and Aulacothyris anatolica (Vadász). Other five loose specimens from the Raricostatum to Ibex Zone interval have been identified as Gibbirhynchia cf. muirwoodae Ager, Callospriferina cf. tumida (Buch) and Liospiriferina alpina (Oppel).

\section{Ankara area, Alacaatl 1}

It is nearly $20 \mathrm{~km}$ to the $\mathrm{SW}$ of the centre of Ankara. The locality was shortly mentioned by Bremer (1965, p. 196, fig. 7). Recently, Deli \& Orhan (2007) made comprehensive field work in this area and published a detailed geological map with a measured section and many photographs illustrating the sedimentary features of the Jurassic series. They showed that the Lower to Middle

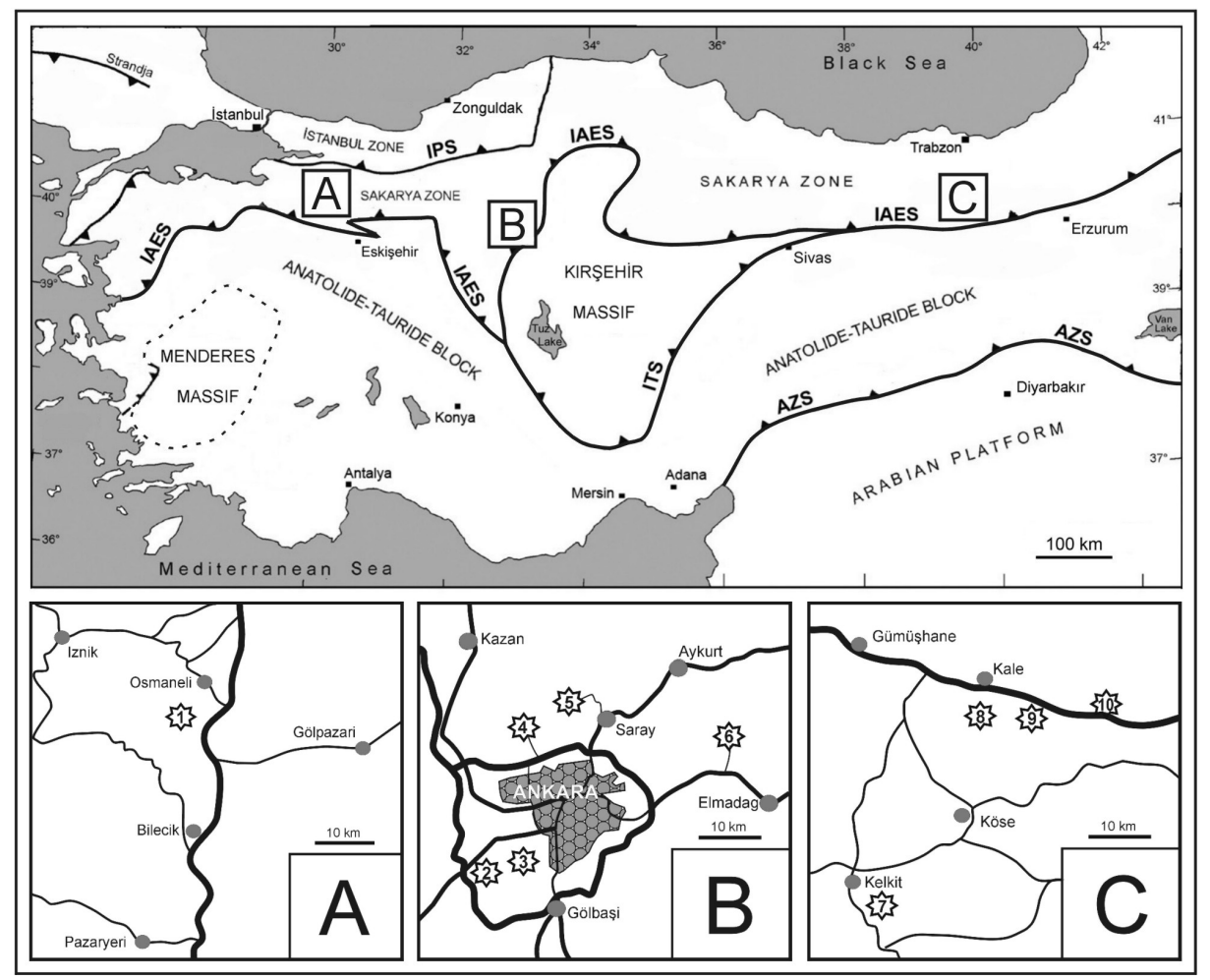

Fig. 1. Geographic situation of the northern Anatolian Early Jurassic brachiopod localities. Tectonic sketch map, simplified after OKAY (2008); IPS = Intra-Pontide Suture; IAES = İzmir-Ankara-Erzincan Suture; ITS = Inner-Tauride Suture; AZS = Assyrian-Zagros Suture. A = Bilecik area; B = Ankara area; $C=$ Gümüşhane area. Numbered localities in star symbols: $1=$ Bilecik, Günüviran; $2=$ Alacaatlı; 3 = Beytepe (Lodumlu); 4 = Yakacik; $5=$ Kösrelik Kızığı; $6=$ Hasanoğlan; $7=$ Kelkit (Dayısı); 8 = Gökdere; 9 = Çalık; $10=$ Elma Tepe 
Table 1. Distribution and number of identified specimens of the Early Jurassic brachiopod taxa collected from diverse localities of Northern Anatolia

\begin{tabular}{|c|c|c|c|c|c|c|c|c|c|c|}
\hline \multirow{3}{*}{ Brachiopod taxa } & \multicolumn{10}{|c|}{ Localities } \\
\hline & \multirow[b]{2}{*}{ 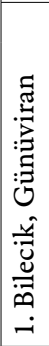 } & \multicolumn{5}{|c|}{ Ankara area } & \multicolumn{4}{|c|}{ Gümüşhane area } \\
\hline & & 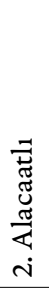 & 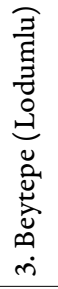 & 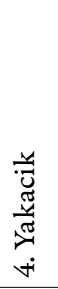 & 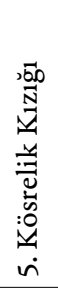 & 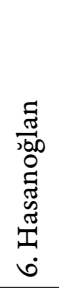 & 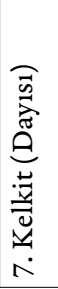 & 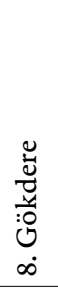 & $\begin{array}{l}\breve{y} \\
\tilde{U}_{n} \\
\dot{a}\end{array}$ & 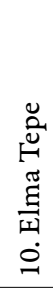 \\
\hline Jakubirhynchia? cf. fascicostata (Uhlig, 1880) & & 1 & & 1 & & & & & & \\
\hline Prionorhynchia? flabellum (Gemmellaro, 1874) & & & & 1 & & & & & & \\
\hline Cirpa fronto (Quenstedt, 1871) & & & & & 1 & & & & & \\
\hline Cirpa borissiaki (Moisseev, 1926) & & 1 & & & & & & & & \\
\hline Cirpa kiragliae Ager, 1959 & & & & & 2 & & & & & \\
\hline Cirpa alkayae sp. n. & & & 3 & & & & & & & \\
\hline Cirpa? sp. & & & & & 1 & & & & & \\
\hline Salgirella alberti (Oppel, 1861) & & & 3 & & & & & & & \\
\hline Calcirhynchia? hungarica (Böckh, 1874) & & & & & & & & & 2 & \\
\hline Homoeorhynchia cf. maninensis (Siblík, 1967) & & & 1 & & & & & & & \\
\hline Cuneirhynchia? aff. palmata (Oppel, 1861) & & & & & 3 & & & & & \\
\hline Cuneirhynchia cf. retusifrons (Oppel, 1861) & & & & & 1 & & & & & \\
\hline Cuneirhynchia dalmasi (Dumortier, 1869) & & & & 8 & 1 & & 1 & & 1 & \\
\hline Cuneirbynchia cf. persinuata (Rau, 1905) & & & & & & & & & 1 & \\
\hline Holcorhynchia? meneghinii (Zittel, 1869) & & & & 1 & & & & & & \\
\hline Gibbirhynchia cf. curviceps (Quenstedt, 1858) & & 2 & 2 & & & & & & & \\
\hline Gibbirhynchia cf. muirwoodae Ager, 1954 & 1 & 2 & & 2 & 1 & & & & & \\
\hline Callospiriferina cf. tumida (Buch, 1837) & 1 & 1 & & & & & & & & \\
\hline Callospiriferina haueri (Suess, 1854) & & 1 & 2 & & & & & & & \\
\hline Liospiriferina alpina (Oppel, 1861) & 3 & 2 & & & & & & 1 & 3 & \\
\hline Liospiriferina obtusa (Oppel, 1861) & & & & & & & & 1 & & \\
\hline Lobothyris cf. punctata (J. Sowerby, 1813) & & 1 & & & & & & & 1 & 3 \\
\hline Linguithyris aspasia (Zittel, 1869) & 3 & & & & & 1 & & & & \\
\hline Zeilleria cf. waterhousi (Davidson, 1851) & & & & & & & & & 1 & \\
\hline Zeilleria cf. lycetti (Davidson, 1851) & & & & & 2 & & & & & \\
\hline Zeilleria cf. subnumismalis (Davidson, 1851) & & & 5 & & & & & & & \\
\hline Zeilleria cf. mutabilis (Oppel, 1861) & & & & & 5 & & & & & \\
\hline Aulacothyris resupinata (J. Sowerby, 1816) & 1 & & & & & & & & & \\
\hline Aulacothyris anatolica (Vadász, 1913) & 4 & & & & 1 & & & & 2 & \\
\hline Bakonyithyris cf. apenninica (Zittel, 1869) & & 2 & & & & & & & & \\
\hline Cincta numismalis (Lamarck, 1819) & & 1 & & & & & & & & \\
\hline Fimbriothyris cf. guerangeri (Desl., 1856) & & & & 1 & & & & & & \\
\hline Number of specimens & 13 & 14 & 16 & 14 & 18 & 1 & 1 & 2 & 11 & 3 \\
\hline
\end{tabular}


Jurassic Bayırköy Formation rests unconformably on the basement of the metamorphosed Karakaya Complex. The crinoidal limestone beds of the SinemurianPliensbachian Uzundere Member are especially rich in brachiopods (Arif Delikan, pers. comm.). The presently described brachiopods (14 specimens) have been collected by F. Alkaya as loose specimens probably from the Upper Pliensbachian. They have been identified as follows:

Gibbirhynchia cf. curviceps (Quenstedt)

Gibbirhynchia cf. muirwoodae Ager

Jakubirhynchia? cf. fascicostata (Uhlig)

Cirpa borissiaki (Moisseev)

Callospiriferina haueri (Suess)

Callospriferina cf. tumida (Buch)

Liospiriferina cf. alpina (Oppel)

Lobothyris cf. punctata (J. Sowerby)

Cincta numismalis (Lamarck)

Bakonyithyris cf. apenninica (Zittel)

On the basis of the known ranges of the above brachiopod species (AGER 1962; Alméras 1964; Vörös 2009), the fauna suggests a Pliensbachian age.

\section{Ankara area, Beytepe}

It is about $15 \mathrm{~km}$ to the $\mathrm{SW}$ of the centre of Ankara. It was mentioned as Lodumlu by BREMER (1965, p. 196), who described that the Liassic is represented by coarse crinoidal calcarenite with limestone and greywacke clasts; this around one hundred metres thick series is intercalated by brachiopodal layers. Most of the presently described brachiopods ( 15 specimens) have been collected by $\mathrm{F}$. Alkaya from a $50-70 \mathrm{~cm}$ thick layer, younger than the Ibex Zone. These brachiopods are unusually large as compared to any other Turkish Liassic brachiopods; they have been identified as follows:

Gibbirhynchia cf. curviceps (Quenstedt)

Homoeorhynchia cf. maninensis (Siblík)

Cirpa alkayae sp. n.

Salgirella alberti (Oppel)

Callospiriferina cf. haueri (Suess)

Zeilleria cf. subnumismalis (Davidson)

One further specimen, identified as Gibbirhynchia cf. curviceps (Quenstedt) has been collected from a $50 \mathrm{~cm}$ thick layer containing redeposited ammonoids of the Raricostatum Zone. 


\title{
Ankara area, Yakacik
}

This is one of the "celebrated localities" of the Liassic of Anatolia (ARKELL 1956, p. 349), about $15 \mathrm{~km}$ northwest of the centre of Ankara. The first reports on the local stratigraphy and palaeontology were given by VADÁsz (1913a, $b$, 1918), who described and illustrated two new brachiopods and listed further 16 brachiopod taxa from the Lower Jurassic brownish red limestones. AgER (1959a) described 11 brachiopod species from Yakacik, partly different from those previously known. Recently Vörös (2014) made a revision and complete description of the Vadász collection and gave an overview of the previous research on the geology and palaeontology of the locality. The presently described brachiopods (14 specimens) have been collected by F. Alkaya as loose specimens said to be coming mainly from the Raricostatum Zone. They have been identified as follows:

\author{
Gibbirhynchia cf. muirwoodae Ager \\ Prionorhynchia flabellum (Gemmellaro) \\ Jakubirhynchia? cf. fascicostata (Uhlig) \\ Cuneirhynchia cf. dalmasi (Dumortier) \\ Holcorhynchia? meneghinii (Zittel) \\ Fimbriothyris cf. guerangeri (Deslongchamps)
}

The known ranges of the above brachiopod species (AgER 1962; ALMÉRAs 1964; VöRös 2009) are restricted to the Pliensbachian (mostly to the Late Pliensbachian); therefore, the dating by Alkaya (Raricostatum Zone) seems to be disproved.

\section{Ankara area, Kösrelik Kızığ}

It is about $15 \mathrm{~km}$ north of the centre of Ankara. The site was mentioned as Kizık by BREMER (1965, p. 194, fig. 9), who described the locality as a wider area of folded Jurassic beds with frequently exposed reddish Lower and Middle Jurassic fossiliferous horizons, and gave a detailed lithological profile of a 200 $m$ thick section starting from the Palaeozoic schists overlain by Lower Jurassic conglomerates and sandstones. It is followed by Sinemurian red limestones and marls, and Pliensbachian greyish marls and nodular limestones, then Bajocian red marls and nodular limestones and terminated by sandy and clayey layers of the higher Middle Jurassic. This seemingly regular Jurassic sequence of beds is akin to that was reported previously from Yakacik, and a great degree of tectonic disturbance can reasonably be supposed also at Kösrelik Kızığı. AlKaYA \& Meister (1995, fig. 3) published a measured section of the Sinemurian part of the sequence with detailed ammonoid stratigraphy. OKAN \& HoşG ÖR (2007) gave a detailed geological map of this area with a measured section, and conveyed 
the idea that the Ammonitico Rosso type sedimentation in the Pontides might be connected to rapidly subsiding seamounts.

The presently described brachiopods ( 18 specimens) have been collected by F. Alkaya as loose specimens coming partly from the Raricostatum to Ibex Zone interval, partly perhaps from the upper Pliensbachian. They have been identified as follows:

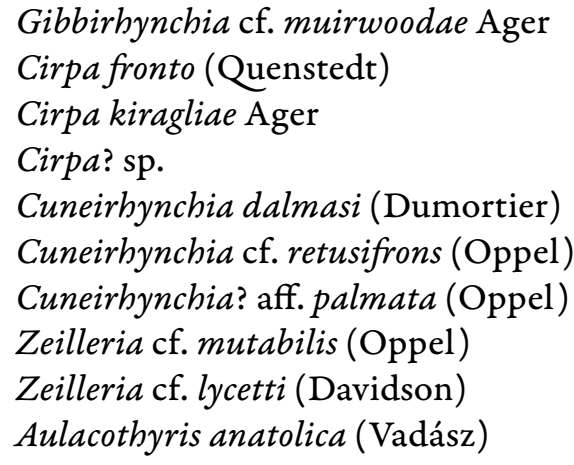

Ankara area, Hasanoğlan

The locality is about $35 \mathrm{~km}$ to the east of Ankara. Its brief geological overview was given by BILGÜTAY (1960), who listed, among many ammonoids, three brachiopod taxa. According to the description by Bremer (1965, p. 198), the Lower Jurassic starts with a basal conglomerate, followed by red crinoidal marls with ammonoids. AlKaYa (1991) published the measured section of the locality with the detailed ammonoid stratigraphy. She collected a single brachiopod, loose from the Sinemurian to Pliensbachian interval, identified here as Linguithyris aspasia (Zittel).

\section{Gümüşhane area, Kelkit (Dayısı)}

This locality lies less than ten kilometres southeast of the town Kelkit, along a valley. Alkaya \& Meister (1995, fig. 13) published a measured section with detailed ammonoid stratigraphy and dated the measured part of the sequence as Sinemurian. A single brachiopod specimen has been collected from this locality by F. Alkaya, identified here as Cuneirhynchia dalmasi (Dumortier).

\section{Gümüşhane area, Gökdere}

This group of localities are found about five kilometres to the south of the village Kale, near a small settlement called Aşagi. Alkaya \& Meister (1995, fig. 7) published a measured section with detailed ammonoid stratigraphy and 
dated the measured part of the sequence as spanning from the lower Sinemurian to the Toarcian. Two brachiopods, collected by F. Alkaya from the Carixian (Ibex Zone), have been identified here as Liospiriferina alpina (Oppel) and L. obtusa (Oppel).

\section{Gümüşhane area, Çalık}

This group of localities lie about one kilometre to the south of the settlement Çalık; a few kilometres to the south of the main road Gümüşhane-Bayburt. Alkaya \& Meister (1995, fig. 9) published a measured section with detailed ammonoid stratigraphy and dated the measured part of the sequence as Lower Pliensbachian (lower to middle Carixian). F. Alkaya collected brachiopods from two different levels. Four brachiopod specimens from the base of the Ibex Zone have been identified as Cuneirhynchia cf. persinuata (Rau), Zeilleria cf. waterhousi (Davidson) and Aulacothyris anatolica (Vadász). Further seven specimens have been found as loose from the Jamesoni to Ibex Zone interval; they have been identified as follows:

Cuneirhynchia cf. dalmasi (Dumortier)
Calcirhynchia? cf. hungarica (Böckh)
Liospiriferina alpina (Oppel)
Lobothyris cf. punctata (J. Sowerby)

Considering the known ranges of the above brachiopod species, the fauna supports the Pliensbachian age dating.

\section{Gümüşhane area, Elma Tepe}

The locality is about $20 \mathrm{~km}$ to the east of the village Kale, on the northern side of the main road Gümüşhane-Bayburt. No further published data on the local geology are available. Three brachiopod specimens have been collected from this locality by F. Alkaya, loose from the Sinemurian to Pliensbachian (Raricostatum to Ibex Zone) interval. They are identified here as Lobothyris cf. punctata (J. Sowerby).

\section{SYSTEMATIC DESCRIPTIONS}

The thirty-one brachiopod species, identified from the ten Lower Jurassic localities of northern Anatolia, will be described and illustrated below. Many of the identified species are frequently illustrated taxa, well-known from the palaeontological literature and do not need detailed description, neither the study of their internal morphology is necessary. In these cases only abridged synonym 
lists and short remarks will be given. Some other forms, with less clear taxonomy, e.g. poorly known, or described as new species, will be discussed more comprehensively. In some of these cases, the internal morphology was also examined and illustrated.

In the systematic descriptions, the classification of the revised "Treatise" (SAVAGe et al. 2002; CARTer \& Johnson 2006; LeE et al. 2006) is followed. The measurements of the figured specimens $(\mathrm{L}=$ length, $\mathrm{W}=$ width, $\mathrm{T}=$ thickness, $\mathrm{Ch}=$ height of the deflection in the anterior commissure) are given in millimetres. The brachiopod material is deposited in the collection of the Department of Palaeontology and Geology of the Hungarian Natural History Museum (HNHM), Budapest. The figured specimens are under the inventory numbers prefixed by "INV" and/or "PAL".

Order Rhynchonellida Kuhn, 1949

Superfamily Pugnacoidea Rzhonsnitskaia, 1956

Family Basiliolidae Cooper, 1959

Subfamily Pamirorhynchiinae Ovcharenko, 1983

Genus Jakubirhynchia Tomašových, 2006

Jakubirhynchia? cf. fascicostata (Uhlig, 1880)

(Figs 2-4)

$\mathrm{v}^{*} 1880$ Rhynchonella fascicostata n. f. - UHLIG, Sospirolo, p. 42, pl. V, figs 1-3.

v 2009 Jakubirhynchia? cf. fascicostata (Uhlig, 1880) - Vörös, Bakony, p. 63, pl. VIII, figs 12, 13 (cum syn.).

Material - Two moderately preserved specimens from Yakacik and Alacaatl (Ankara area), Pliensbachian.

Measurements -

\begin{tabular}{lcccc}
\hline & L & W & T & Ch \\
\hline INV 2014.92. & 10.5 & 11.6 & 5.4 & 2.2 \\
\hline
\end{tabular}

Remarks - This small and rather flat rhynchonellid species was thoroughly discussed recently by VöRös (2009) and was placed tentatively to the genus Jakubirhynchia. The present material did not allow investigation of the internal features; therefore, this tentative generic attribution is accepted here. J. fascicostata is very easy to separate from other rhynchonellids because it is entirely and finely ribbed and the bifurcate ribs appear in bundles posteriorly. J. fascicostata is widespread in the Sinemurian and Pliensbachian of the Alpine-Mediterranean region and now it is recorded from northern Anatolia. 
Superfamily Rhynchotetradoidea Licharew, 1956

Family Prionorhynchiidae Manceñido \& Owen, 2002

Genus Prionorhynchia Buckman, 1918

Prionorhynchia? flabellum (Gemmellaro, 1874)

(Figs 11-13)

v *1874 Rhynchonella flabellum, Menegh. - Gemmellaro, Zona con Terebratula Aspasia, p. 83 (partim), pl. XI, figs 25-27, (non fig. 14).

v 2009 Prionorhynchia ? flabellum (Gemmellaro, 1874) - VöRös, Bakony, p. 68, pl. VIII, fig. 5 (cum syn.).

Material - One rather well-preserved specimen from Yakacik (Ankara area), Pliensbachian.

Measurements -

\begin{tabular}{lcccc}
\hline & L & W & T & Ch \\
\hline INV 2014.95. & 13.4 & 14.0 & 7.1 & - \\
\hline
\end{tabular}

Remarks - This very characteristic rhynchonellid species was thoroughly discussed recently by the present author (VöRös 2009) and was placed tentatively to the genus Prionorhynchia. The single specimen was not suitable to investigate the internal features; therefore, this tentative generic attribution is accepted here. P. flabellum can be distinguished from other species of Prionorhynchia by its laterally expanded subtrigonal, flabelliform outline and straight anterior commissure, with coarse zig-zag deflections. P. flabellum is a characteristic Pliensbachian species of the Alpine-Mediterranean region and this is its first record from northern Anatolia.

\author{
Superfamily Wellerelloidea Licharew, 1956 \\ Family Wellerellidae Licharew, 1956 \\ Subfamily Cirpinae Ager, 1965 \\ Genus Cirpa de Gregorio, 1930
}

Cirpa fronto (Quenstedt, 1871)

(Figs 5-7)

* 1871 [Terebratula] triplicata fronto - QUENSTEDT, Petrefactenkunde Deutschlands, p. 71, pl. 37, figs 177-183.

1934 Rhynchonella variabilis Dav. var. fronto Quenst. - Morsseiev, Crimea and Caucasus, p. 43, 178 , pl. II, figs 30-33.

1959 b Cirpa fronto (Quenstedt). - AGER, British Rhynchonellidae, p. 53, text-figs 29-30, pl. V, figs 1-3.

1964 Cirpa fronto (Quenstedt, 1871) - SiBLÍ́, Belanska Dolina, p. 168, text-fig. 3, pl. VIII, figs 4-6. 
? 2003 Cirpa fronto (Quenstedt, 1871) - DulaI, Hettangian and Early Sinemurian, p. 17, text-fig. 4, pl. II, figs 1-3.

? 2010 Cirpa fronto (Quenstedt, 1871) - Alméras et al., Massif Armoricain, p. 28, text-fig. 18, pl. 2, fig. 2, pl. 5, fig. 4 .

v 2011 Cirpa fronto (Quenstedt, 1871) - Vörös \& KAndemir, Eastern Pontides, p. 353, fig. 4/1 (cum syn.).

2012 Cirpa fronto (Quenstedt 1871) - HöFLINGER, Deutsch. Lias, p. 39 + fig. (unnumbered).

Material - One well preserved specimen from Kösrelik Kızı̆̆ı (Ankara area), loose, from Sinemurian to Pliensbachian interval.

\begin{tabular}{lcccc} 
Measurements - & \multicolumn{1}{l}{} \\
\hline & $\mathrm{L}$ & $\mathrm{W}$ & $\mathrm{T}$ & $\mathrm{Ch}$ \\
\hline INV 2014.93. & 10.3 & 10.9 & 7.6 & 7.2 \\
\hline
\end{tabular}

Remarks - This well-known and typical species of the genus Cirpa was recently figured and discussed by VöRös \& KANDEMIR (2011) from Turkey. The above synonymy contains more items but far from being complete. The specimen figured by DULAI $(2003,1 . c$.$) does not show the diagnostic flattened frontal$ region of $C$. fronto, therefore, that identification is queried. The same holds true for the record by AlmÉRAs et al. $(2010,1 . c$.$) where the ribbing is too much coarse$ and the anterior view is missing. This Pliensbachian species is cosmopolitan in distribution, occurring in Northwest Europe, the Alpine-Mediterranean region, in the Atlas Mts, the Crimea and Turkey.

Cirpa borissiaki (Moisseiev, 1926)

(Figs 8-10)

*1926 Rhynchonella Borissiaki n. sp. - MoIsseiev, Crimea, p. 971, 991, pl. XXVIII, figs 5-7.

1934 Rhynchonella borissiaki n. sp. - Moisseiev, Crimea and Caucasus, p. 45,178 (pars), pl. II, figs 46-48, (non pl. III, figs 1-4).

1989 Cirpa borissiaki (Moisseiev, 1934) - Tсноumatchenco, Kotel I, p. 6, text-figs 2, 3, pl. VI, figs 1-5.

v 2011 Cirpa cf. borissiaki (Moisseiev, 1934) - Vörös \& KANDEMIR, Eastern Pontides, p. 354, fig. $4 / 2$.

Material - One moderately preserved specimen from Alacaatlı (Ankara area), Pliensbachian.

Measurements -

\begin{tabular}{lcccc}
\hline & $\mathrm{L}$ & $\mathrm{W}$ & $\mathrm{T}$ & $\mathrm{Ch}$ \\
\hline INV 2014.94. & 10.8 & 12.6 & 8.6 & 6.2 \\
\hline
\end{tabular}

Remarks - This is a small Cirpa with high oval outline and somewhat "cynocephalous" lateral view. The uniplicate anterior commissure shows four narrowly spaced, sharp zig-zag deflections. The ornamentation consists of 8 to 9 regular ribs, which are weak on the posterior part and became very sharp anteriorly. C. borissia- 
$k i$ differs from $C$. fronto by its very narrow uniplication and that it has no anterior flattening. Vörös \& KANDEMIR $(2011,1$.c.) described this species and cited Moisseiev, 1934 as author. However, the correct date is 1926, since Moisseiev (1926, 1.c.) properly described and figured the species borissiaki. So far, C. borissiaki was reported only from the Pliensbachian of the Pontian region (Crimea, Bulgaria, Turkey).
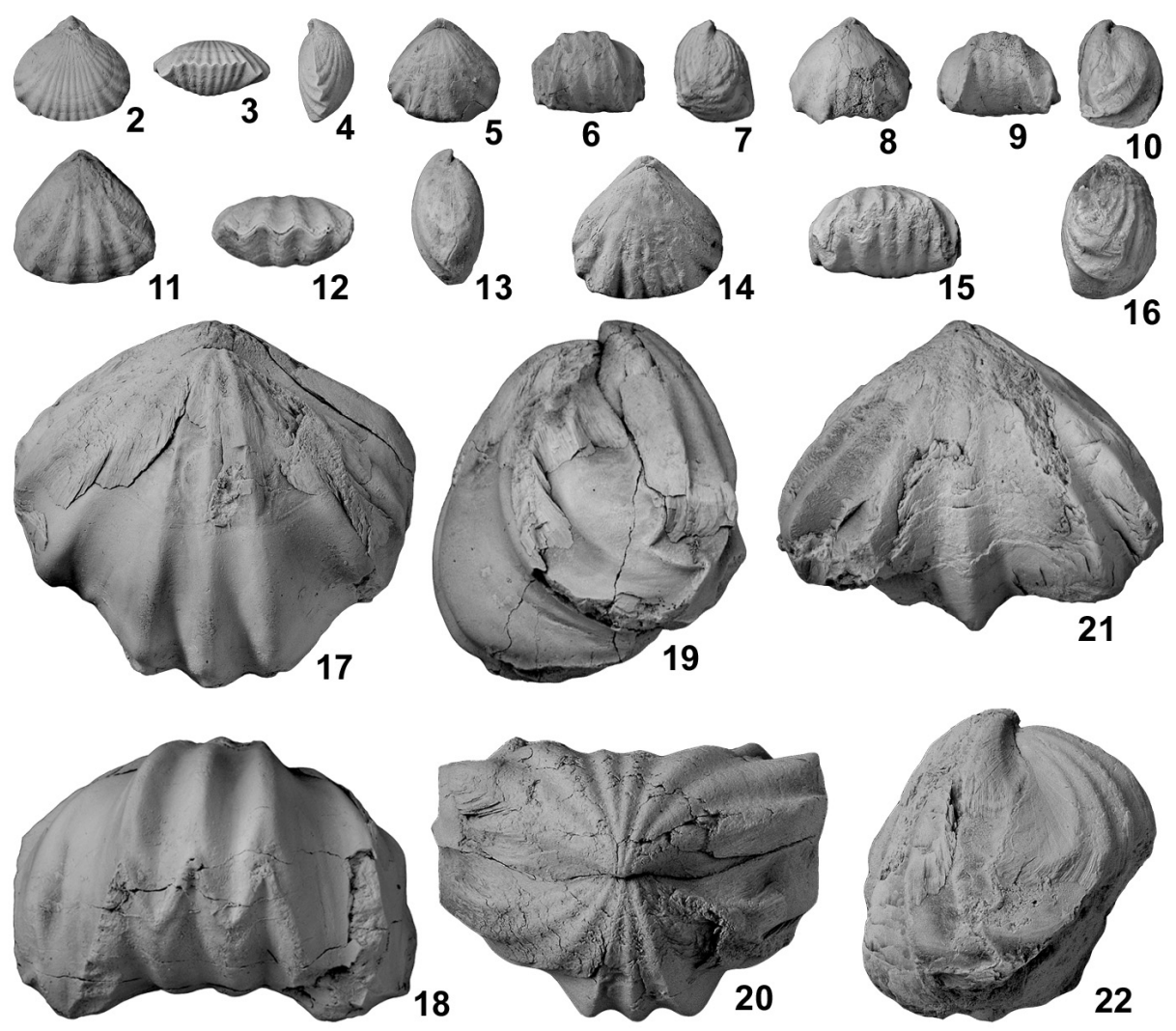

Figs 2-4. Jakubirhynchia? cf. fascicostata (Uhlig, 1880), INV 2014.92., Yakacik, Pliensbachian, $2=$ dorsal view, 3 = anterior view, $4=$ lateral view. - Figs 5-7. Cirpa fronto (Quenstedt, 1871), INV 2014.93., Kösrelik Kızığı, loose, from Sinemurian to Pliensbachian interval, 5 = dorsal view, 6 = anterior view, 7 = lateral view. - Figs 8-10. Cirpa borissiaki (Moisseiev, 1926), INV 2014.94., Alacaatl, Pliensbachian, $8=$ dorsal view, $9=$ anterior view, $10=$ lateral view. - Figs 11-13. Prionorhynchia? flabellum (Gemmellaro, 1874), INV 2014.95., Yakacik, Pliensbachian, $11=$ dorsal view, 12 = anterior view, 13 = lateral view. - Figs 14-16. Cirpa kiragliae Ager, 1959, INV 2014.96., Kösrelik Kızığı, loose, from Sinemurian to Pliensbachian interval, $14=$ dorsal view, $15=$ anterior view, 16 = lateral view. - Figs 17-20. Cirpa alkayae sp. n., holotype: PAL 2014.137., Beytepe, Pliensbachian, 17 = dorsal view, $18=$ anterior view, $19=$ lateral view, $20=$ posterior view. - Figs 21-22. Cirpa alkayae sp. n., INV 2014.97., Beytepe, Pliensbachian, incomplete specimen with two folds in the uniplication, 21 = ventral view, 22 = lateral view. (All figures are in natural size. Specimens have been coated with ammonium chloride before photography.) 
Cirpa kiragliae Ager, 1959

(Figs 14-16)

* 1959a Cirpa kiragliae Ager, n. sp. - AGER, Turkey, p. 1019, text-fig. 2, pl. 128, fig. 2. v 2014 Cirpa cf. kiragliae Ager, 1959 - VöRös, Yakacik, p. 236, pl. I, fig. 6.

Material - Two moderately preserved specimens from Kösrelik Kızığı (Ankara area), loose, from Sinemurian to Pliensbachian interval.

Measurements -

\begin{tabular}{lcccc}
\hline & L & W & T & Ch \\
\hline INV 2014.96. & 14.4 & 15.3 & 9.4 & 6.4 \\
\hline
\end{tabular}

Remarks - This is a rather coarsely costate species of the genus Cirpa, which differs from the typical species by its less convex valves and the absence or weak development of the anterior flattening. It has 11 ribs, five of which are in the uniplication. C. kiragliae was described by AGER (1959a) from Yakacik (Turkey) and was recorded recently from the same locality by the present author (VöRös 2014). Both authors discussed the relationships of C. kiragliae to other species of Cirpa. C. kiragliae seems to be endemic for Turkey (northern Anatolia).

Cirpa alkayae sp. n.

(Figs 17-20, 21-22, 23)

Holotypus - Hungarian Natural History Museum (Budapest), inventory number: PAL 2014.137.

Locus typicus - Beytepe (Lodumlu), Ankara area, Turkey.

Stratum typicum - Pink crinoidal limestone, Pliensbachian.

Paratypus - Hungarian Natural History Museum (Budapest), inventory number: PAL 2014.138.

Derivatio nominis - After the name of Füsun Alkaya, who collected the brachiopod specimens.

Diagnosis - Very large, strongly costate Cirpa with highly uniplicate anterior commissure and depressed beak. Double deltidial plates; strongly crenulated hinge teeth. Long, ventrally arched crura of hamiform type.

Material - Three specimens, one well-preserved (holotype) and two partly fragmentary articulated valves from Beytepe (Lodumlu), Ankara area, Pliensbachian.

\begin{tabular}{ccccc} 
Measurements - & \multicolumn{5}{c}{} \\
\hline & $\mathrm{L}$ & $\mathrm{W}$ & $\mathrm{T}$ & $\mathrm{Ch}$ \\
\hline PAL 2014.137. (holotype) & 37.0 & 40.8 & 30.2 & 24.2 \\
PAL 2014.138. (paratype) & $>32.0$ & 39.1 & 26.8 & - \\
\hline
\end{tabular}

Description - External characters: Large Cirpa with rounded subpentagonal outline. The apical angle is around $115^{\circ}$. The maximum width is attained at 
around the middle of the length or a little more posteriorly. The valves are moderately to strongly convex; the maximum convexity lies near mid-length. The ventral valve is more convex than the dorsal which is somewhat depressed at its middle portion. The beak is low, pointed, and erect. The foramen is poorly preserved but seems to be mesothyrid. The delthyrium is rather narrow and high; the deltidial plates are convex. The beak ridges are blunt but demarcate long, moderately deep planareas. In lateral view, the lateral commissures are gently sinuous: in their posterior part they are strongly arched dorsally, then they run straight in the middle of the planareas; near the anterolateral extremities they bear zigzag deflections with increasing amplitude. The anterior commissure shows a high and trapezoidal uniplication. It is strongly serrated, with 2 to 4 zig-zag deflections of uniform strength. The valves are multicostate throughout, with only a few posterior intercalations. The number of ribs varies from 8 to 10 ( 9 in the type specimen); 2 to 4 of which are in the uniplication (3 in the type specimen). The anterior flattening, in spite of the large, adult specimens, is weak or absent.

Internal characters (Fig. 23): Ventral valve: The delthyrial cavity is high trapezoidal in cross-section. The umbonal cavities are narrow triangular. Pedicle collar was not observed. The posterior part of the deltidial plates are fused and arched; then they divide and seem to form double plates. The dental plates are strong and converge ventrally. The hinge teeth are rather elongated and strongly crenulated; denticula are marked. Dorsal valve: Cardinal process is low. Short, rudimentary dorsal median septum is seen posteriorly. The outer socket ridges are very strong. The inner socket ridges are high, oblique and poorly demarcated from the outer hinge plates. The outer hinge plates are directed ventrally then become subhorizontal. The crural bases emerge dorsolaterally and give rise to rather long, ventrally arched crura of hamiform type.

Remarks - From among other species of the genus, Cirpa alkayae sp. n. stands the closest to C. briseis (Gemmellaro, 1874), especially to the larger specimens figured by Di STEFANo (1891, pl. III, figs 9, 11). The present author examined the original material of Gemmellaro and Di Stefano in the collections of the Palermo University and made plaster casts of the figured specimens. The comparison convinced the author that $C$. alkayae is a separate species. Notably, the beak of $C$. alkayae is much more depressed and it is significantly larger than any known specimens of $C$. briseis. The close overall similarity to C. briseis (a typical species of the genus) and the internal features (double deltidial plates, hamiform crura) justify the attribution of the new species alkayae to the genus Cirpa.

Occurrence - Up to now, C. alkayae is known only from the type locality, Beytepe (Lodumlu), Ankara area, Turkey, from the Pliensbachian $(50-70 \mathrm{~cm}$ thick layer, younger than Ibex Zone, according to the written communication by Füsun Alkaya, 1992). 

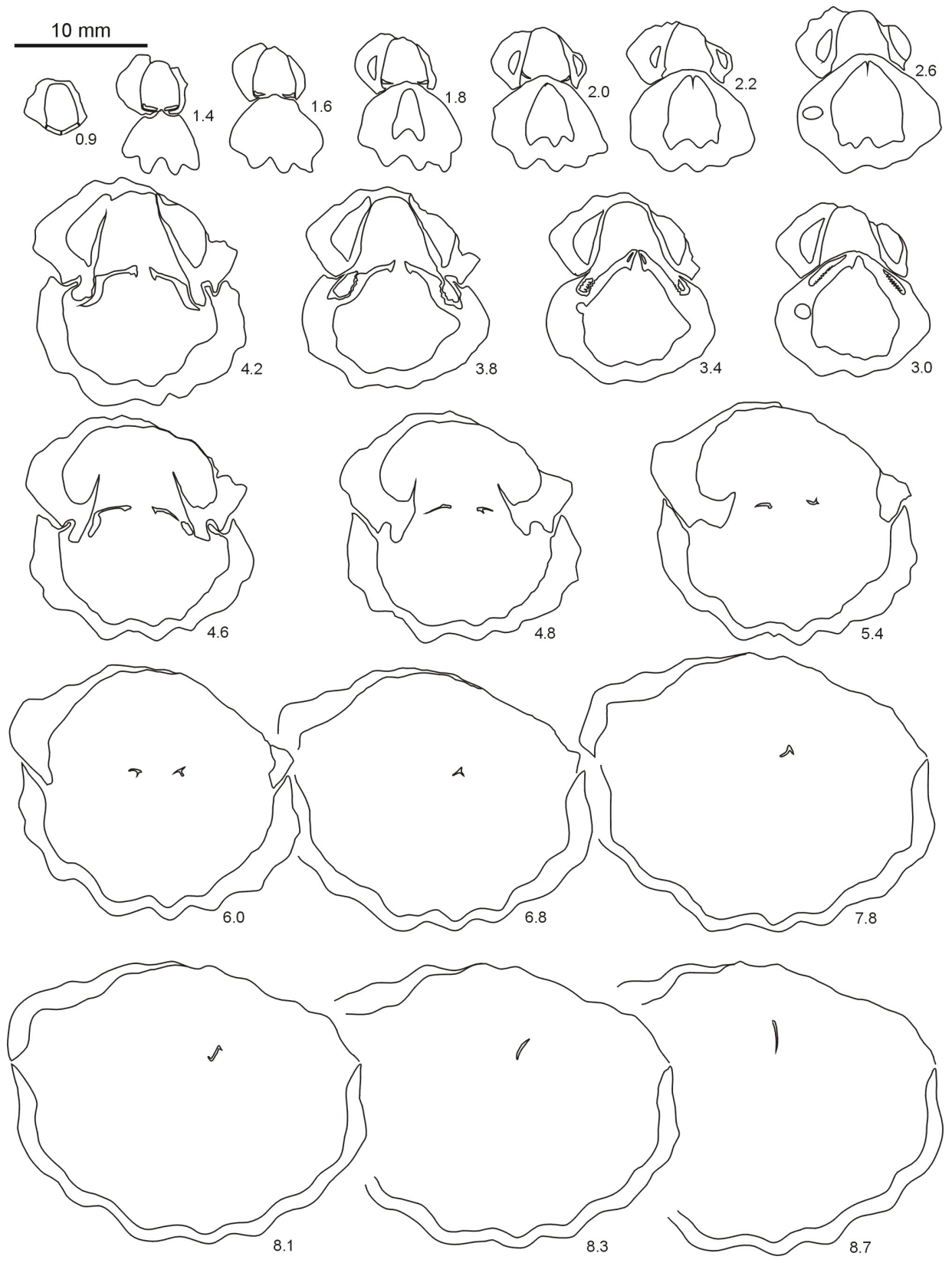

Fig. 23. Cirpa alkayae sp. n. Twenty transverse serial sections through the posterior part of a specimen from Beytepe (Lodumlu), Pliensbachian. Paratype: PAL 2014.138. Distances from posterior end of the shell are given in $\mathrm{mm}$. Original length of the specimen was $\sim 36.0 \mathrm{~mm}$ 
Genus Salgirella Moisseev, 1936

Salgirella alberti (Oppel, 1861)

(Figs 24-26)

* 1861 Rhynchonella Albertii Opp. - OppeL, Brachiopoden des unteren Lias, p. 546, pl. XIII, fig. 4. ? 1869 Rhynchonella Alberti (Oppel). - Dumortier, Bassin du Rhône, p. 332, pl. XLII, figs 14, 15. v 1880 Rhynchonella Albertii Oppel. - UHLIG, Sospirolo, p. 32 (pars), pl. IV, fig. 1 (non fig. 2).

v 1889 Rhynchonella Alberti Opp. - GeYER, Hierlatz, p. 43, pl. V, figs 14-17.

v 1895 Rhynchonella Alberti Opp. - FUCINI, Calcari bianchi, p. 172, pl. VII, fig. 1.

v 1900 Rhynchonella sp. aff. Alberti Opp. - Böse \& SCHLOSSER, Südtyrol, p. 193, pl. XVIII, fig. 1. 1934 Rhynchonella alberti Opp. - MoIsseiev, Crimea and Caucasus, p. 46, 179, pl. III, figs 5-7.

1949 Rhynchonella Alberti Opp. var. tenuis n. var. - Nutsubidze, Dzirula Massif, p. 49, pl. I, fig. 5. ? 2003 Salgirella cf. alberti (Oppel, 1861) - DulaI, Hettangian and Early Sinemurian, p. 29, pl. V, figs $7-10$.

2008 Salgirella albertii (Oppel, 1861) - Si вLí́, Mitterwand, p. 66, pl. 1, fig. 2.

Material - Three partly incomplete specimens from Beytepe (Ankara area), probably Pliensbachian.

Measurements -

\begin{tabular}{lcccc}
\hline & L & W & T & Ch \\
\hline INV 2014.98. & 26.3 & 33.5 & 14.6 & 7.9 \\
\hline
\end{tabular}

Remarks - This is the type species of the genus Salgirella, and it was profusely and properly illustrated in the classical literature (OPPEL 1861, l.c.; GeYER 1889, 1.c.) and even by MoIsSeiev (1934, l.c.). On this basis, our specimens were easily identified as $S$. alberti. The illustrations of $S$. alberti given by Dumortier (1869, 1.c.) and DULAI $(2003,1 . c$.$) are not fully convincing; they probably represent some$ other species. The same holds true for one of the figures by UHLIG (1880, pl. IV, fig. 2); the present author examined this specimen in the collection of the Padova University, and concluded that it may belong rather to the genus Prionorhynchia.

The original spelling of the name albertii by OPPEL (1.c.) has been changed by GEYER (1.c.) to alberti; later this usage became prevailing, therefore, in accordance with the rules of the ICZN (ICZN 1999, Article 33.3), alberti is suggested as the correct spelling. S. alberti is a characteristic Sinemurian Alpine species, but it was recorded also from the Pliensbachian of other Mediterranean localities, the Crimea and Caucasus and now from Turkey.

Genus Calcirhynchia Buckman, 1918

Calcirhynchia? hungarica (Böckh, 1874)

(Figs 27-29)

*1874 Rhynchonella Hungarica n. sp. - Böc KH, Südlichen Theiles des Bakony, p. 160, pl. IV, figs 5, 6. 1884 Rhynchonella Hungarica Böckh. 1874. - HAAs, Südtyrol und Venetien, p. 8, pl. II, fig. 12. 
v 2009 Calcirhynchia ? hungarica (Böckh, 1874) - VöRös, Bakony, p. 78, pl. VIII, fig. 11 (cum syn.). v 2014 Calcirhynchia hungarica (Böckh, 1874) - Vörös, Yakacik, p. 236, pl. I, fig. 4.

Material - Two moderately preserved specimens from Çalık (Gümüşhane area), loose from Lower Pliensbachian.

\begin{tabular}{lcccc} 
Measurements - & \multicolumn{3}{l}{} \\
\hline \multicolumn{1}{l}{ L } & W & T & Ch \\
\hline INV 2014.99. & 12.1 & 14.0 & 9.2 & 4.8 \\
\hline
\end{tabular}

Remarks - This rather globose, uniplicate and fully costate species was recently discussed by Vörös $(2009,2014)$; that served the basis of the identification of our specimens.

" $R$." hungarica was described by BӧсKн (1874), who recognized its similarity to " $R$." plicatissima Quenstedt, 1852, but mentioned some differences between the two species. Subsequently, many authors regarded the two species as synonymous, with plicatissima as senior synonym. Recently, following the detailed revisions by ToMAšovÝcH (2006) and considering the data given by DulaI (1992, 2003), VöRös (2009) restored Böckh's species name hungarica for the forms which do not have planareas, but show fine riblets on their flat or gently convex lateral parts. The species hungarica is placed here to Calcirhynchia on the basis of serial sections of "Calcirhynchia plicatissima", published by DulaI $(1992,2003)$. C. hungarica was widely recognized in the Sinemurian and Pliensbachian of the AlpineMediterranean region, but was recently recorded also in south Germany and Turkey.

Superfamily Rhynchonelloidea d'Orbigny, 1847

Family Rhynchonellidae d'Orbigny, 1847

Subfamily Rhynchonellinae d'Orbigny, 1847

Genus Homoeorhynchia Buckman, 1918

Homoeorhynchia cf. maninensis (Siblík, 1967)

(Figs 30-32)

* 1967 blovenirhynchia maninensis sp. n. - SibLí K, Domerian, p. 161, text-figs 4-9, pl. X, figs 1-4, pl. XI, figs 1-3.

1967 S Slovenirhynchia slovenica sp. n. - SiBLíK, Domerian, p. 165, text-figs 10-12, pl. XII, figs 2-4. ? 1989 Homoeorhynchia almaensis (Moisseiev, 1934) - TсHоUмAтCHENCO, Kotel I, p. 18 (pars), pl. II, figs 1-5 (non figs 6-9).

Material - One slightly damaged specimen from Beytepe (Ankara area), probably Pliensbachian.

\begin{tabular}{lcccc} 
Measurements - & \multicolumn{1}{c}{} \\
\hline & $\mathrm{L}$ & $\mathrm{W}$ & $\mathrm{T}$ & $\mathrm{Ch}$ \\
\hline INV 2014.100. & 13.1 & 15.4 & 8.1 & 7.9 \\
\hline
\end{tabular}


Remarks - Our specimen has laterally expanded subquadrangular outline, weak deflections on its lateral commissures and biplicate anterior margin with two, sharp, equidimensional (i.e. perfectly symmetrical) deflections. The characters of its beak also support its attribution to the genus Homoeorhynchia.

The Turkish specimen is extremely similar to those figured by SIBLÍK (1967b) on pl. X, fig. 1, as Slovenirhynchia maninensis and on pl. XII, fig. 3, as S. slovenica (the junior synonym of maninensis), therefore it was identified as maninensis. Siblík's genus Slovenirhynchia was taken as synonymous with Homoeorhynchia (Sučić-Protić 1969; Ager 1983). This was also accepted by Siblík (1999, and pers. comm.), who considered maninensis as a representative of a morphological group within Homoeorbynchia, which was characterized by less cynocephalous (i.e. somewhat depressed) shape and symmetrically developed biplication. This "maninensis-group" differs from the examples mentioned by AGER (1983) in the "marginal populations" of $H$. acuta (J. Sowerby, 1816), bearing two or three sharp deflexions in their anterior commissures. These specimens of the marginal population have always asymmetrically developed secondary riblets or weak deflexions on the sides of the high uniplication, as illustrated by MoIsseiev (1934, pl. V, figs 10, 11), AGER (1959a, text-fig. 1) and Vörös (2014, pl. I, figs 7, 8) from Yakacik (Turkey) and VöRös (2009, pl. IX, fig. 5) from Hungary.

Some other species, as possible members of the "maninensis-group", e.g. $H$. steinmanni (Haas \& Petri, 1882) and H. solitaria Siblík, 1999 were mentioned by SibLÍ K (1999), who discussed the differences between them as well. Further related forms were illustrated by SučIć-PROTIĆ (1969) under the name Planirhynchia tantilla sp. nov. and by ТСHOUM ATCHENCO (1989) as Homoeorhynchia almaensis (Moisseiev, 1934). Especially some specimens figured by TсHOUMATCHENCo (1989, pl. II, figs 1-5) seem very similar to $H$. maninensis by their highly and sharply biplicate anterior commissure. It has to be mentioned, that the original specimen of „Rhynchonella” almaensis figured by MoISSEIEV (1934, pl. III, figs 51-54) is not biplicate, but shows three zig-zag deflections of different altitude. H. maninensis was recorded from the Upper Pliensbachian of the West Carpathians and the Balkans (Kotel) and now from northern Anatolia.

Subfamily Piarorhynchiinae Shi \& Grant, 1993

Genus Cuneirhynchia Buckman, 1918

Cuneirhynchia? aff. palmata (Oppel, 1861)

(Figs 33-35)

Material - Three rather well-preserved specimens from Kösrelik Kızığı (Ankara area), loose, from Sinemurian to Pliensbachian interval. 


\begin{tabular}{lcccc} 
Measurements - & \multicolumn{1}{c}{} \\
\hline & $\mathrm{L}$ & $\mathrm{W}$ & $\mathrm{T}$ & $\mathrm{Ch}$ \\
\hline INV 2014.101. & 13.9 & 16.0 & 7.7 & 3.8 \\
\hline
\end{tabular}

Remarks - This species probably belongs to the genus Cuneirhynchia on the basis of the planareas bordered by sharp ventral beak ridges; the slightly arched lateral commissures running close to the ventral beak ridges; the strongly deflected and nearly straight anterior commissure and the few (4 to 5), strong ribs, which appear only anteriorly. It stands close to C. palmata (Oppel, 1861), portrayed properly by OPPEL (1861, pl. XIII, fig. 2), UhLIG (1880, pl. V, fig. 4) and partly by GEYER $(1889$, pl. VI, figs $11,13,14)$, but differs from that by having fewer ribs (4-5, in contrast to 6-12 in C. palmata) and by undulate anterior commissure in contrast to the sharp deflections of $C$. palmata. Therefore, this species is described here as a separate taxon and only the affinity indicated.

\section{Cuneirhynchia cf. retusifrons (Oppel, 1861)}

(Figs 36-38)

* 1861 Rhynchonella retusifrons Opp. - OPPEL, Brachiopoden des unteren Lias, p. 544, pl. XII, fig. 5. v 1874 Rhynchonella retusifrons, Opp. - Gemmellaro, Zona con Terebratula Aspasia, p. 76, pl. XI, fig. 17.

v 1889 Rhynchonella retusifrons Opp. - GEYER, Hierlatz, p. 62 (pars), pl. VII, figs 8, 9, 11, 12 (non fig. 10).

1993 Cuneirhynchia retusifrons (Oppel, 1861) - Si BLÍk, Steinplatte, p. 968, pl. 1, fig. 10.

2003 Cuneirhynchia retusifrons (Oppel, 1861) - DulaI, Hettangian and Early Sinemurian, p. 37, pl. VI, figs 11-13.

v 2003 Cuneirhynchia retusifrons (Oppel, 1861) - VöRös et al., Schafberg, p. 72, pl. VI, figs 38-40.

2012 Cuneirhynchia retusifrons (Oppel 1861) - Höflinger, Deutsch. Lias, p. 63 + fig. (unnumbered).

2012 Cuneirhynchia cf. retusifrons (Oppel 1861) - HöFLINGER, Deutsch. Lias, p. $64+$ fig. (unnumbered).

Material - One partly broken specimen from Kösrelik Kızığı (Ankara area), loose, from Sinemurian to Pliensbachian interval.

\begin{tabular}{ccccc} 
Measurements - & L & W & T & Ch \\
\hline INV 2014.102. & $\sim 11.0$ & 15.4 & 7.8 & 2.3 \\
\hline
\end{tabular}

Remarks - This species of Cuneirhynchia differs from C. palmata (Oppel, 1861) by its low but marked, trapezoidal uniplication and more numerous but weak ribs. Our specimen has 13 ribs, 7 of which are in the uniplication. The anterior segment of the wide subtrigonal outline is truncated or even slightly concave. C. retusifrons was reported from the Sinemurian to the Pliensbachian. It is typically Alpine-Mediterranean in distribution, though HöFLINGER (2012, l.c.) 
reported it from southern Germany with the notion that the extra-Alpine forms have more numerous ribs. The Turkish specimen is also densely ribbed.

\section{Cuneirhynchia dalmasi (Dumortier, 1869)}

(Figs 39-41)

* 1869 Rhynchonella Dalmasi (Nov. spec.). - Dumortier, Bassin du Rhône, p. 331, pl. XLII, figs 3-5.

1962 Cuneirhynchia dalmasi (Dumortier). - AGER, British Rhynchonellidae, p. 126, text-figs 7780, pl. XI, figs 4, 5 .

2012 Cuneirhynchia dalmasi (Dumortier 1869) - HöFLINGER, Deutsch. Lias, p. 62 + fig. (unnumbered).

v 2014 Cuneirhynchia dalmasi (Dumortier, 1869) - Vörös, Yakacik, p. 238, pl. I, figs. 9, 10 (cum syn.).

Figs 24-26. Salgirella alberti (Oppel, 1861), INV 2014.98., Beytepe, Pliensbachian, $24=$ dorsal view, 25 = anterior view, 26 = lateral view. - Figs 27-29. Calcirhynchia ? hungarica (Böckh, 1874), INV 2014.99., Çalık, loose from Lower Pliensbachian, $27=$ dorsal view, $28=$ anterior view, $29=$ lateral view. - Figs 30-32. Homoeorhynchia cf. maninensis (Siblík, 1967), INV 2014.100., Beytepe, Pliensbachian, 30 = dorsal view, 31 = anterior view, 32 = lateral view. - Figs 33-35. Cuneirhynchia? aff. palmata (Oppel, 1861), INV 2014.101., Kösrelik Kızı̆̆ı, loose, from Sinemurian to Pliensbachian interval, $33=$ dorsal view, $34=$ anterior view, $35=$ lateral view. - Figs 36-38. Cuneirhynchia cf. retusifrons (Oppel, 1861), INV 2014.102., Kösrelik Kızı̆̆ interval, 36 = dorsal view, 37 = anterior view, $38=$ lateral view. - Figs 39-41. Cuneirhynchia dalmasi (Dumortier, 1869), INV 2014.103., Kösrelik Kızığ interval, 39 = dorsal view, 40 = anterior view, 41 = lateral view. - Figs 42-44. Cuneirhynchia cf. persinuata (Rau, 1905), INV 2014.104., Çalık, Lower Pliensbachian, $42=$ dorsal view, 43 = anterior view, 44 = lateral view. - Figs 45-47. Holcorhynchia? meneghinii (Zittel, 1869), INV 2014.105., Yakacik, Pliensbachian, $45=$ dorsal view, $46=$ anterior view, $47=$ lateral view. - Figs 48-50. Gibbirhynchia cf. curviceps (Quenstedt, 1856), INV 2014.106., Beytepe, Pliensbachian, $48=$ dorsal view, 49 = anterior view, 50 = lateral view. - Figs 51-53. Gibbirhynchia cf. muirwoodae Ager, 1954, INV 2014.107., Günüviran, loose from uppermost Sinemurian to lower Pliensbachian interval, 51 = dorsal view, 52 = anterior view, 53 = lateral view. - Figs 54-56. Gibbirhynchia $\mathrm{cf}$. muirwoodae Ager, 1954, INV 2014.108., Yakacik, Pliensbachian, $54=$ dorsal view, $55=$ anterior view, $56=$ lateral view. - Figs 57-59. Callospiriferina cf. tumida (Buch, 1837), INV 2014.109., Günüviran, Upper Sinemurian to Pliensbachian, $57=$ dorsal view, 58 = anterior view, $59=$ lateral view. - Fig. 60. Callospiriferina haueri (Suess, 1854), INV 2014.111., Beytepe, Pliensbachian, ventral view. Figs 61-63. Callospiriferina haueri (Suess, 1854), INV 2014.110., Alacaatl1, Pliensbachian, $61=$ posteroventral view, 62 = anteroventral view, 63 = lateral view. - Figs 64-66. Liospiriferina alpina (Oppel, 1861), INV 2014.112., Günüviran, Sinemurian to Pliensbachian, $64=$ dorsal view, $65=$ anterior view, 66 = lateral view. - Figs 67-69. Liospiriferina alpina (OPPEL, 1861), INV 2014.113., Gökdere, Pliensbachian, 67 = posterior view, 68 = anterior view, $69=$ lateral view. - Figs 70-72. Liospiriferina obtusa (Oppel, 1861), INV 2014.114., Gökdere, Pliensbachian, 70 = posterior view, 71 = anterior view, 72 = lateral view. - Figs 73-75. Lobothyris cf. punctata (J. Sowerby, 1813), INV 2014.115., Çalık, Pliensbachian, $73=$ dorsal view, $74=$ anterior view, $75=$ lateral view. (All figures are in natural size. Specimens have been coated with ammonium chloride before photography.) 

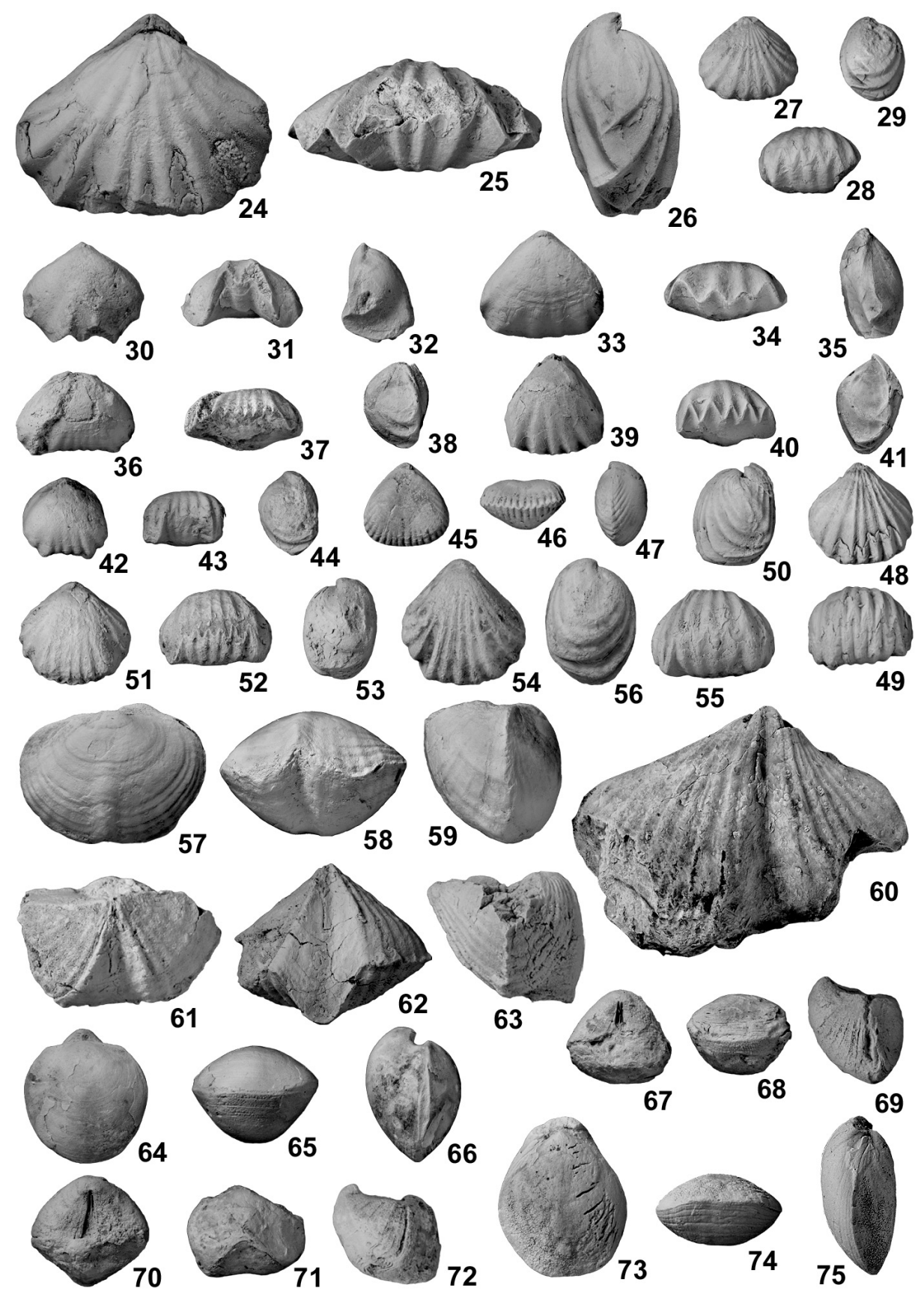
Material - Eleven variously preserved specimens from Yakacik and Kösrelik Kızığı (Ankara area) and Kelkit and Çalık (Gümüşhane area), from Sinemurian to Pliensbachian interval.

Measurements -

\begin{tabular}{lcccc}
\hline & $\mathrm{L}$ & $\mathrm{W}$ & $\mathrm{T}$ & $\mathrm{Ch}$ \\
\hline INV 2014.103. & 13.0 & 12.7 & 8.5 & 3.8 \\
\hline
\end{tabular}

Remarks - This is the type species of the genus Cuneirhynchia with an outline close to an equilateral triangle, lateral commissures running near the extremely sharp ventral beak ridges. Further important characters are the very wide, low trapezoidal uniplication with sharp zig-zag deflections and the few, strong ribs, which appear only after a posterior smooth area. C. dalmasi is a Pliensbachian species cosmopolitan in distribution from the NW-European and Mediterranean regions to Turkey.

Cuneirhynchia cf. persinuata (Rau, 1905)

(Figs 42-44)

* 1905 Rhynchonella persinuata n. sp. - RAU, Lias Schwabens, p. 296, pl. XXII, figs 62-69.

1934 Rhynchonella persinuata Rau. - MoIsseiev, Crimea and Caucasus, p. 55, 182, pl. IV, figs 1-8. 1964 Cuneirhynchia ? persinuata (Rau, 1905) - SiBLík, Belanska Dolina, p. 175, text-fig. 6, pl. VIII, fig. 2.

1967 a Cuneirhynchia persinuata (Rau, 1905) - Siblík, Slov. domer, p. 15, text-fig. 2, pl. I, fig. 2.

1989 Cuneirhynchia persinuata (Rau, 1905) - TChoumatchenco, Kotel I, p. 21, text-fig. 14, pl. III, figs 7-9.

2012 Cuneirhynchia persinuata (Rau 1905) - Höflinger, Deutsch. Lias, p. 60 + figs. (unnumbered).

Material - One rather poorly preserved specimen from Çalık (Gümüşhane area), Lower Pliensbachian.

Measurements -

\begin{tabular}{lcccc}
\hline & L & W & T & Ch \\
\hline INV 2014.104. & 10.6 & 11.3 & 7.7 & 4.9 \\
\hline
\end{tabular}

Remarks - This species was well-documented by profuse illustrations by RAU (1905, l.c.) and HöFLINGER (2012, 1.c.) and on this basis, the identification of our specimen seems satisfactory. C. persinuata stands very close to the type species of the genus, C. dalmasi (Dumortier, 1869), but it is more convex, has more numerous ribs, weaker deflections in the uniplication, and its outline is more pentagonal in dorsal view, with somewhat concave anterior part. C. persinuata is a characteristic late Pliensbachian brachiopod of the NW-European (German) region but it was recorded also from the Pliensbachian of the West Carpathians, the Balkans (Kotel), the Crimea and now from the Pontides (Turkey). 
Superfamily Norelloidea Ager, 1959

Family Norellidae Ager, 1959

Subfamily Diholkorhynchiinae Xu \& Liu, 1983

Genus Holcorhynchia Buckman, 1918

Holcorhynchia? meneghinii (Zittel, 1869)

(Figs 45-47)

v*1869 Rhynchonella Meneghinii Zitt. - Zittel, Central-Appenninen, p. 130, pl. XIV, figs 10, 11.

v 2014 Holcorhynchia meneghinii (Zittel, 1869) - Vörös, Yakacik, p. 238, text-fig. 2, pl. I, fig. 12

(cum syn.).

Material - One well preserved specimen from Yakacik (Ankara area), Pliensbachian.

Measurements -

\begin{tabular}{lcccc}
\hline & $\mathrm{L}$ & $\mathrm{W}$ & $\mathrm{T}$ & $\mathrm{Ch}$ \\
\hline INV 2014.105. & 11.1 & 11.3 & 6.5 & 1.8 \\
\hline
\end{tabular}

Remarks - This is a rarely illustrated species, which was previously known only from the Central Appennines. Now it seems that $H$. meneghinii is rather frequent in Turkey: besides the present record, it was mentioned by VADÁsz (1918) and documented in details by Vörös (2014). The author examined the original material of ZitTel (1869) in the Bayerische Staatssammlung (München) and confirmed that the tiny "Rhynchonella" meneghinii is characterized by subtriangular outline, faint ribs which develop just near the anterior margin and a shallow dorsal sulcus; the anterior margin is only slightly sulcate. On these grounds our specimens from Yakacik can definitely be identified with Holcorhynchia meneghinii. AGER (1959a) described a closely related species, H. yakacikensis Ager, 1959 from Yakacik, which is, however, significantly more elongated than meneghinii. H. meneghinii was recorded from the Pliensbachian of the Central Appennines and Turkey.

Superfamily Hemithyridoidea Rzhonsnitskaia, 1956

Family Tetrarhynchiidae Ager, 1959

Subfamily Gibbirhynchiinae Manceñido \& Owen, 2002

Genus Gibbirhynchia Buckman, 1918

Gibbirhynchia cf. curviceps (Quenstedt, 1856)

(Figs 48-50)

* 1856 Terebratula curviceps - Quenstedt, Der Jura, p. 138, pl. 17, figs 13-15.

v 2009 Gibbirhynchia cf. curviceps (Quenstedt, 1858) - VöRös, Bakony, p. 103, pl. XI, fig. 16 (cum syn.).

2010 Gibbirhynchia curviceps (Quenstedt, 1856) - Alméras et al, Massif Armoricain, p. 28, textfigs 8,9 , pl. 3, figs 1,2 , pl. 5 , fig. 5 . 
v 2011 Gibbirhynchia cf. curviceps (Quenstedt, 1856) - VöRös \& KANDEMIR, Eastern Pontides, p. 354, fig. 4/4.

2012 Gibbirhynchia curviceps (Quenstedt 1858) - HöFLINGER, Deutsch. Lias, p. 86 + figs. (unnumbered).

2013 Gibbirhynchia curviceps (Quenstedt, 1858) - AlmÉRAs \& FAURÉ, Quercy, p. 45, pl. 3, figs 15, 16.

2013 Gibbirhynchia curviceps (Quenstedt, 1856) - AlmÉRAs \& Cougnon, Principaux genres, p. 127, pl. 14, figs 9-11.

Material - Four variously preserved specimens from Beytepe and Alacaatl (Ankara area), probably Pliensbachian.

\begin{tabular}{lcccc} 
Measurements - & \multicolumn{1}{c}{} \\
\hline L & W & T & Ch \\
\hline INV 2014.106. & 12.4 & 14.7 & 6.7 & 5.2 \\
\hline
\end{tabular}

Remarks - G. curviceps is perhaps the most frequently cited Pliensbachian rhynchonellid species in Europe. It was profusely illustrated by ALmÉrAs et al. (2010, 1.c.), Alméras \& Cougnon (2013, 1.c.) and HöFlinger (2012, 1.c.) what served a firm basis for the identification of our specimens. G. curviceps was recorded in a great number of localities in the Mediterranean region as well and when I was able to check personally in the respective collections, I recognized that $G$. curviceps became a comfortably used collective taxon among the numerous and partly vaguely defined species of the genus Gibbirhynchia. The date of publication of this species is inconsistently cited by different authors as 1856 or 1858 . Quenstedt's "Der Jura" was published in several parts in different years; the species curviceps was described in the first part (p. 138) therefore the proper date is 1856. G. curviceps is a Pliensbachian species with cosmopolitan geographical distribution.

\section{Gibbirhynchia cf. muirwoodae Ager, 1954}

(Figs 51-53, 54-56)

* 1954 Gibbirhynchia muir-woodae sp. nov. - AgER, Gibbirhynchia, p. 40, pl. 1, figs 5, 6.

1962 Gibbirhynchia muirwoodae Ager. - AGER, British Rhynchonellidae, p. 99, text-fig. 60, pl. VIII, fig. 8.

Material - Six variously preserved specimens from Günüviran (Bilecik area), Yakacik, Kösrelik Kızı̆̆ı and Alacaatlı (Ankara area), Upper Sinemurian to Pliensbachian.

Measurements -

\begin{tabular}{lcccc}
\hline & L & W & T & Ch \\
\hline INV 2014.107. & 13.8 & 14.8 & 9.9 & $\sim 5.5$ \\
INV 2014.108. & 16.6 & 16.2 & 11.7 & 7.7 \\
\hline
\end{tabular}

Remarks - This medium-sized Gibbirhynchia differs from G. curviceps (Quenstedt, 1856) in the lower degree of convexity of its valves and in some fea- 
tures what approach to the genus Tetrarhynchia, e.g. the shape of the fold and the costation. Considering the illustrations given by AGER (1954, l.c. and 1962, 1.c.), our specimens seem to show the greatest similarity to G. muirwoodae from among the many species of Gibbirhynchia. G. muirwoodae was recorded from the upper Pliensbachian of the NW-European region and Turkey.

Order Spiriferinida Ivanova, 1972

Suborder Spiriferinidina Ivanova, 1972

Superfamily Pennospiriferinoidea Dagys, 1972

Family Lepismatinidae Xu \& Liu, 1983

Subfamily Dispiriferininae Carter, 1994

Genus Callospiriferina Rousselle, 1965

\section{Callospiriferina cf. tumida (Buch, 1837)}

(Figs 57-59)

* 1837 Spirifer tumidus. - BuCH, Über Delthyris, p. 53.

1971 Spiriferina tumida var. typica var. nov. - Sučić-Protić, Mid. Lias. Brach. Yugosl. CarpathoBalkanids (II), p. 51, pl. XVIII, figs 1-5, pl. XXXVI, fig. 2.

1977 Callospiriferina tumida (v. Buch) - Rousselle, Spiriférines, p. 157, text-figs 1-B, 3, 4, pl. 1, fig. 2.

2000 Callospiriferina tumida (v. Buch, 1836) - Alméras \& Fauré, Pyrénées, p. 206, text-fig. 38, pl. 22, figs $7,8$.

2003 Callospiriferina tumida (Buch, 1836) - DulaI, Hettangian and Early Sinemurian, p. 66, pl. XII, figs 1-4.

2010 Callospiriferina tumida (V. Buch, 1836) - Alméras et al., Massif Armoricain, p. 65, pl. 4, fig. 15 , pl. 5 , fig. 3.

2012 Callospiriferina tumida (v. Buch 1837) - HöFlinger, Deutsch. Lias, p. 93 + fig. (unnumbered).

2013 Callospiriferina tumida (V. Buch, 1834) - Alméras \& Cougnon, Principaux genres, p. 21, pl. 1, figs 1, 2 .

Material - Two specimens; one fragmentary specimen from Günüviran (Bilecik area), and a disarticulated ventral valve from Alacaatlı (Ankara area), loose from Upper Sinemurian to Pliensbachian interval.

Measurements -

\begin{tabular}{lcccc}
\hline & $\mathrm{L}$ & $\mathrm{W}$ & $\mathrm{T}$ & $\mathrm{Ch}$ \\
\hline INV 2014.109. & $\sim 20.0$ & 24.2 & 16.2 & $\sim 4.0$ \\
\hline
\end{tabular}

Remarks - This is the type species of the genus Callospiriferina, defined by ROUSSELLE (1977) as comprising the weakly ribbed spiriferinides with well-demarcated, smooth dorsal fold and ventral sulcus. Despite that its ventral beak is broken away, our specimens, especially the figured one, corresponds very well to the above description and to the figures cited in the synonymy. 
In the original description of $C$. tumida (under the name "Spirifer tumidus") BuCH (1837, p. 53) made reference to "Spirifer pinguis Ziethen, 1830", and introduced the name tumidus for substituting the name pinguis, which was preoccupied for a Carboniferous species of "Spirifer". Nevertheless, the name pinguis remained popular for a long time, and many authors used it, until Sučić-Protić (1971, p. 50) then Rousselle (1977) cleared up this confusion. C. tumida is a Sinemurian to Pliensbachian species of widespread distribution from the NWEuropean and Alpine-Mediterranean regions to North Africa and Turkey.

Callospiriferina haueri (Suess, 1854)

(Figs 60, 61-63)

* 1854 Spirifer Haueri Suess. - Suess, Kössener Schichten, p. 52, pl. II, fig. 6.

v 1886 Sp. Haueri Suess 1854 - Roth PLETZ, Vilser-Alpen, p. 162, pl. XIII, figs 1-5.

? 1934 Spiriferina ex gr. tumida Corroy. - Moisseiev, Crimea and Caucasus, p. 28, 175, pl. I, figs 26-28.

1934 Spiriferina haueri Suess. - MoIsseiev, Crimea and Caucasus, p. 28, 175, pl. I, figs 29, 30, pl. II, figs 1-4.

1971 Spiriferina tumida (Buch) var. haueri Corroy - SučIć-Protić, Mid. Lias. Brach. Yugosl. Carpatho-Balkanids (II), p. 52, pl. XIX, figs 1-4.

1990 Spiriferina haueri Suess, 1854 - Tchoumatchenco, Brach. jur. Kotel II., p. 4 (pars), text-fig. 1, pl. I, figs 1, 5, 7 (? non figs 2, 4, 6), pl. II, figs 3-5 (? non figs 1, 2).

1999 Callospiriferina haueri (Suess 1854) - SiBLÍ́, Northern Calcareous Alps, p. 429, pl. 3, figs 2, 3.

2012 Callospiriferina haueri (Suess 1854) - HöFLINGER, Deutsch. Lias, p. 95 + fig. (unnumbered).

Material - Three fragmentary specimens from Beytepe and Alacaatlı (Ankara area), probably Pliensbachian.

\begin{tabular}{lcccc}
\multicolumn{2}{c}{ Measurements - } & \multicolumn{5}{c}{} \\
\hline & $\mathrm{L}$ & $\mathrm{W}$ & $\mathrm{T}$ & $\mathrm{Ch}$ \\
\hline INV 2014.110. & $>18.0$ & 26.4 & 19.2 & 7.7 \\
INV 2014.111. & $>30.0$ & $\sim 44.0$ & - & - \\
\hline
\end{tabular}

Remarks - This is a large Callospiriferina with laterally expanded oval to subtrigonal outline. The hinge margin is straight and very wide, its length attains the whole width of the shell, and protrudes from the outline. The valves are almost equally convex. The dorsal valve is more inflated posteriorly. The ventral umbo is wide, very high and strongly apsacline. The interarea is a little wider than high and almost flat. The dorsal umbo is well developed. The lateral commissures are poorly preserved. The anterior commissure is highly uniplicate forming a narrow, rather sharp, unbroken arch. The linguiform extension is distinctly protracted anterodorsally. The lateral flanks of the valves are covered by 7 to 9 strong but blunt ribs; the central fold and sulcus are smooth.

C. haueri is well-documented by classical authors (SUEss 1854; ROTHPLETZ 1886) and our specimens from the Ankara area fit well to these illustrations. The 
specimen illustrated by Morsseiev (1934, pl. I, figs 26-28) as Spiriferina ex gr. tumida Corroy seems rather similar to $C$. haueri. From among the numerous specimens illustrated by Tсhoum AтсHenco (1990) as haueri, some items are queried in the above synonymy because their figures are of very poor quality, or they are almost smooth. This species has a cosmopolitan distribution from the Alpine region to Turkey and from the Hettangian to the Pliensbachian.

Superfamily Spiriferinoidea Davidson, 1884

Family Spiriferinidae Davidson, 1884

Subfamily Spiriferininae Davidson, 1884

Genus Liospiriferina Rousselle, 1977

Liospiriferina alpina (Oppel, 1861)

(Figs 64-66, 67-69)

* 1861 Spiriferina alpina Opp. - Oppel, Brachiopoden des unteren Lias, p. 541, pl. XI, fig. 5.

v 2009 Liospiriferina alpina (Oppel, 1861) - Vörös, Bakony, p. 112, pl. XII, fig. 2 (cum syn.).

non 2013 Liospiriferina alpina (Oppel, 1861) - Alméras \& Cougnon, Principaux genres, p. 30, pl. 2, fig. 6.

v 2014 Liospiriferina alpina (Oppel, 1861) - Vörös, Yakacik, p. 240, pl. I, fig. 14.

Material - Nine partly incomplete specimens from Günüviran (Bilecik area), Alacaatlı (Ankara area), Gökdere and Çalık (Gümüşhane area), Upper Sinemurian and Pliensbachian.

\begin{tabular}{lcccc}
\multicolumn{2}{c}{ Measurements - } & \multicolumn{5}{c}{} \\
\hline & $\mathrm{L}$ & $\mathrm{W}$ & $\mathrm{T}$ & $\mathrm{Ch}$ \\
\hline INV 2014.112. & 17.5 & 15.6 & 12.2 & - \\
INV 2014.113. & 13.1 & 12.7 & 10.2 & - \\
\hline
\end{tabular}

Remarks - This frequently cited and figured Alpine species of the genus Liospiriferina was recently discussed in detail by Vörös (2009). L. alpina is easily identified on the basis of its circular outline, the simple, smooth biconvex valves, the straight anterior commissure and the elevated ventral beak with rather high, trigonal interarea. AlmÉrAs \& Cougnon (2013, p. 30) suggested that the item L. alpina by Vörös (2009) should be referred to L. hartmanni (Zieten, 1830). However, this can not be accepted, because $L$. hartmanni clearly differs from $L$. alpina by having transversely elongated outline, uniplicate anterior commissure and massive dorsal umbo. The specimen figured by ALMÉras \& COUGNON $(2013,1 . c$.$) does not correspond to the typical L. alpina because its anterior com-$ missure is not straight but definitely uniplicate. L. alpina is a typical Sinemurian to Pliensbachian Alpine-Mediterranean species but it was rarely recorded also from NW-Europe, Algeria and Turkey. 


\title{
Liospiriferina obtusa (Oppel, 1861)
}

(Figs 70-72)

* 1861 Sp. obtusa - OpPeL, Brachiopoden des unteren Lias, p. 542, pl. XI, fig. 8.

v 2009 Liospiriferina obtusa (Oppel, 1861) - Vörös, Bakony, p. 115, pl. XIII, fig. 1 (cum syn.).

Material - One moderately preserved specimen from Gökdere (Gümüşhane area), Lower Pliensbachian.

Measurements -

\begin{tabular}{lcccc}
\hline & L & W & T & Ch \\
\hline INV 2014.114. & 15.3 & 14.6 & 12.0 & 6.9 \\
\hline
\end{tabular}

Remarks - L. obtusa is closely related to L. alpina but it is markedly uniplicate and its ventral beak is strongly apsacline and slightly incurved. The relationship of L. obtusa to other species of Liospiriferina was discussed recently by Vörös (2009). L. obtusa is a typical Sinemurian to Pliensbachian Alpine-Mediterranean species but it was rarely recorded also from the southern regions of NW-Europe, the Crimea and Turkey.

\author{
Order Terebratulida Waagen, 1883 \\ Suborder Terebratulidina Waagen, 1883 \\ Superfamily Loboidothyridoidea Makridin, 1964 \\ Family Lobothyrididae Makridin, 1964 \\ Subfamily Lobothyridinae Makridin, 1964 \\ Genus Lobothyris Buckman, 1918
}

Lobothyris cf. punctata (J. Sowerby, 1813)

(Figs 73-75)

* 1813 Terebratula punctata. - J. Sowerby, Mineral Conchology I, p. 46, pl. XV, fig. 4.

1926 Terebratula punctata Sow. - MoIsseIEv, Crimea, p. 975, pl. XXVIII, figs 23-25.

v 2009 Lobothyris cf. punctata (J. Sowerby, 1813) - VöRös, Bakony, p. 137, pl. XV, fig. 6 (cum syn.).

v 2011 Lobothyris punctata (Sowerby, 1813) - VöRös \& KANDEMIR, Eastern Pontides, p. 357, figs $5 / 1-2$.

v 2014 Lobothyris cf. punctata (J. Sowerby, 1813) - VöRös, Yakacik, p. 242, pl. II, fig. 3.

Material - Five specimens of various state of preservation from Alacaatl (Ankara area), Elma Tepe and Çalık (Gümüşhane area), Upper Sinemurian to Pliensbachian.

\begin{tabular}{lcccc} 
Measurements - & & & \\
\hline & $\mathrm{L}$ & $\mathrm{W}$ & $\mathrm{T}$ & $\mathrm{Ch}$ \\
\hline INV 2014.115. & 21.2 & 15.8 & 9.3 & - \\
\hline
\end{tabular}


Remarks - This widespread Early Jurassic terebratulid species was very frequently recorded and figured in the classical and recent literature. In spite of its very simple morphology: elongated oval outline, somewhat flattened dorsal valve, rectimarginate commissures, and relatively small, depressed ventral umbo, $L$. punctata is easy to recognize and the identification of our specimens seems justified. L. punctata is a Pliensbachian species of cosmopolitan distribution.

\author{
Superfamily Dyscolioidea Fischer \& Oehlert, 1892 \\ Family Nucleatidae Schuchert, 1929 \\ Genus Linguithyris Buckman, 1918
}

Linguithyris aspasia (Zittel, 1869)

(Figs 76, 77-79, 80-82, 83-85)

v* 1869 Terebratula Aspasia. Menegh. - ZItT te, Central-Appenninen, p. 126, pl. XIV, figs 1-4.

v 2009 Linguithyris aspasia (Zittel, 1869) - Vörös, Bakony, p. 169, text-figs 96-104, pl. XXIV, figs 5-13, pl. XXV, figs 1-11, pl. XXVI, figs 1-6 (cum syn.).

2012 Linguithyris aspasia (Meneghini 1853) - HöfLINGER, Deutsch. Lias, p. 144 + fig. (unnumbered).

2013 Linguithyris aspasia (Zittel, 1869) - BAEZA-CARratalá, Subbetic, p. 84, fig. 5/10.

v 2014 Linguithyris aspasia (Zittel, 1869) - Vörös, Yakacik, p. 242, pl. II, fig. 5.
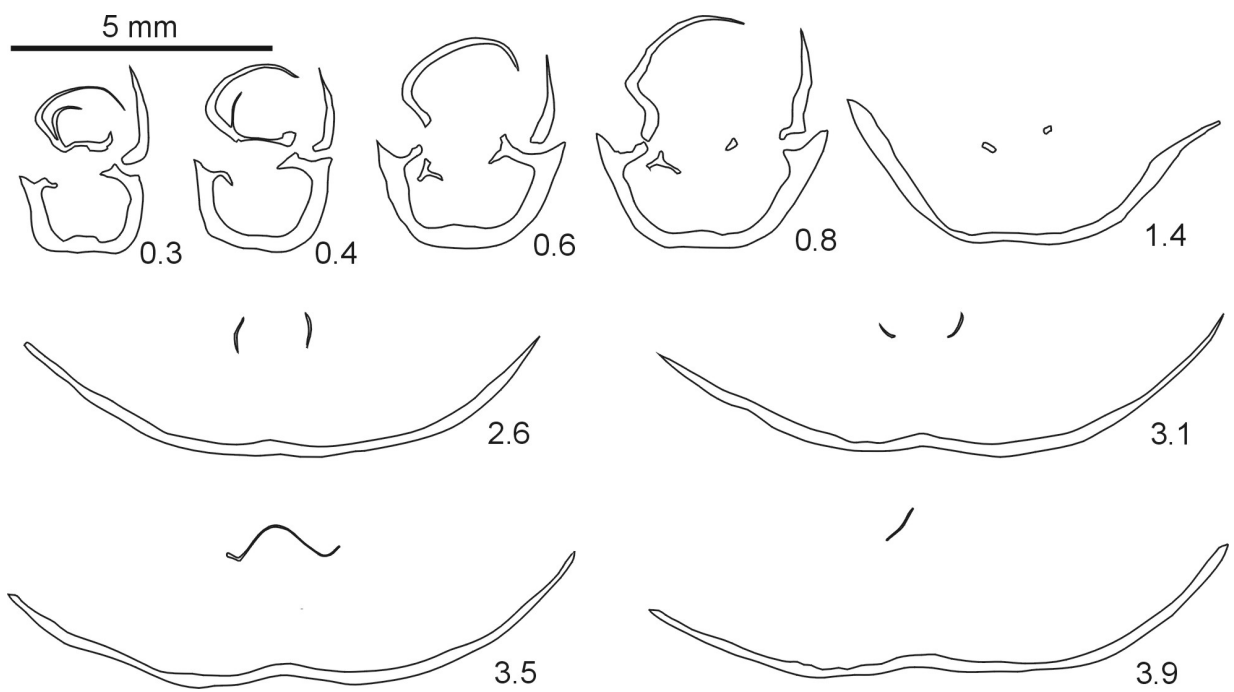

Fig. 76. Linguithyris aspasia (Zittel, 1869). Nine transverse serial sections through the posterior part of a specimen from Bilecik, Günüviran (Turkey), loose from Upper Sinemurian to Carixian interval, INV 2014.119. Distances from posterior end of the shell are given in $\mathrm{mm}$. Original length of the specimen was $11.0 \mathrm{~mm}$. (The umbonal part of the ventral valve was seriously damaged) 
Material - Four specimens of various state of preservation from Günüviran (Bilecik area) and Hasanoğlan (Ankara area), loose from Upper Sinemurian to Pliensbachian interval.

\begin{tabular}{lcccc}
\multicolumn{2}{c}{ Measurements - } & \multicolumn{5}{c}{} \\
\hline & $\mathrm{L}$ & $\mathrm{W}$ & $\mathrm{T}$ & $\mathrm{Ch}$ \\
\hline INV 2014.116. & $\sim 13.0$ & 14.6 & 10.0 & - \\
INV 2014.117. & 10.0 & 12.5 & 7.0 & 4.9 \\
INV 2014.118. & 12.9 & 14.1 & 9.8 & 7.5 \\
\hline
\end{tabular}

Remarks - This species was profusely illustrated and exhaustively discussed by Vörös (2009) and the identification of our specimens is beyond doubt. It is worth mentioning that all Turkish specimens, including those figured by AGER (1959a, 1991) and VöRös (2014) represent the isometric variants of $L$. aspasia; they did not reach the bilobate growth stage. Nevertheless, they definitely belong to $L$. aspasia, what is further supported by the internal features illustrated by AGER (1991, fig. 2) and by the present paper (Fig. 76). Both series of cross sections show the reduced hinge plates, the indistinct crural bases, triangular in cross section and the simple loop with arched transverse band. One specimen figured by Tсноumatchenco (1990, pl. VII, fig. 3) from Kotel, may represent a juvenile $L$. aspasia. This is a long-ranging species, from the Sinemurian to the early Toarcian.

Its frequent occurrence in the lower Pliensbachian of the Mediterranean region initiated the classical term "Strati con T. aspasia". Later on, the geographical distribution of this species was proved to extending to a wider area, including North Africa and Turkey.

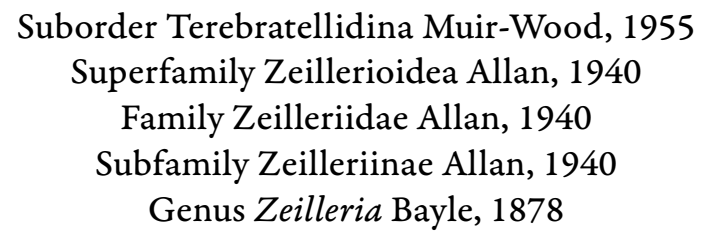

Zeilleria cf. waterhousi (Davidson, 1851)

(Figs 86-88)

* 1851 Terebratula Waterhousii, Dav. - Davidson, Oolitic and Liasic, p. 31, pl. V, figs 12, 13. 1869 Terebratula Waterhousi (Davidson). - Dumortier, Bassin du Rhône, p. 324, pl. XLI, figs 11, 12. 2012 Zeilleria waterhousi (Davidson 1851) - HöFLINGER, Deutsch. Lias, p. 169 + fig. (unnumbered). v 2014 Zeilleria cf. waterhousi (Davidson, 1851) - Vörös, Yakacik, p. 243, pl. II, fig. 6.

Material - One moderately preserved specimen from Çalık (Gümüşhane area), Lower Pliensbachian. 


\begin{tabular}{lcccc} 
Measurements - & \multicolumn{1}{c}{} \\
\hline & $\mathrm{L}$ & $\mathrm{W}$ & $\mathrm{T}$ & $\mathrm{Ch}$ \\
\hline INV 2014.120. & 14.6 & 11.0 & 5.8 & - \\
\hline
\end{tabular}

Remarks - In the identification of this species the comprehensive synthesis on zeilleriids by DeLANCE (1974) and the monographs by Alméras \& FAURÉ $(2000,2013)$ have been taken into account. In the original concept by DAvidson (1851) T. waterhousi was characterized by gently sulcate anterior commissure. Later, by synonymizing the species subdigona (Oppel, 1853) the forms with straight anterior commissure were also included (DELANCE 1974; Alméras \& FAURÉ 2013). Our specimen shows gently strangulate, straight anterior commissure, therefore stands closer to the "subdigona"-type.

Antoshtchenko (1970) ranged this species into the genus Keratothyris Tuluweit, 1965, but it was not accepted by DeLANCE (1974) and later French authors, and this latter opinion is followed by the present author. Z. waterhousi was most frequently recorded in northwest Europe, but occurs also in the Crimea, the Balkans and Turkey; therefore, it seems to be cosmopolitan in distribution.

\section{Zeilleria cf. lycetti (Davidson, 1851)}

(Figs 89-91)

* 1851 Terebratula Lycetii, Dav. - DAvidson, Oolitic and Liasic, p. 44, pl. VII, figs 17-19 (non figs 20-22).

non 1878 Waldheimia Lycetti, Dav. - Davidson, Supplement, p. 175, pl. XXIV, figs 30, 31.

1974 Zeilleria lycetti (Davidson 1851, sensu Buckman 1904) - DelanCE, Zeilleridés, p. 158, pl. 2, figs $11,12$.

? 1994 Zeilleria (Zeilleria) lycetti (Davidson, 1851) - Tсноumatchenco, Ouarsenis, p. 55, pl. V, figs $4,5$.

2010 Zeilleria lycetti (Davidson, 1851 sensu Buckman, 1904) - Alméras et al., Massif Armoricain, p. 58, text-fig. 18, pl. 4, figs 3, 4 .

v 2011 Zeilleria cf. lycetti (Davidson, 1851) sensu Ager - Vörös \& KANDEMIR, Eastern Pontides, p. 358, fig. 5/5 (cum syn.).

v 2014 Zeilleria cf. lycetti (Davidson, 1851) - Vörös, Yakacik, p. 244, pl. II, fig. 7.

Material - Two partly incomplete specimens from Kösrelik Kızığı (Ankara area), loose from Upper Sinemurian to Pliensbachian interval.

Measurements -

\begin{tabular}{lcccc}
\hline & L & W & T & Ch \\
\hline INV 2014.121. & 17.7 & 14.5 & 8.3 & - \\
\hline
\end{tabular}

Remarks - This species of Zeilleria has very simple morphology. Its outline is slightly drop-shaped, oval; the valves are moderately and nearly equally convex. The beak is highly elevated and suberect, with sharp beak ridges. The commissures are rectimarginate. Dental plates are visible in specimens with broken umbo. By these morphological features, our specimens were easily identified as $Z$. cf. lycetti. 
Z. lycett $i$ is frequently cited and illustrated but its correct interpretation bears some uncertainty. DAVIDSON (1851, pl. VII, figs 17-22) figured several different specimens under the name lycetti. BUCKMAN (1904) revised the material and designated the specimen on fig. 17 by DAvidson (1851) as the type specimen of “Ornithella Lycetti". Delance (1974) and later French authors (AlmÉras et al. 2010; AlmÉrAs \& FAURÉ 2013) followed this practice. On the other hand, AGER (1959a) used a wider interpretation and included the figs 17-19 of DAVIDSON (1851) as representing the species $Z$. lycetti. This was accepted by VöRös \& KANDEMIR (2011) and Vörös (2014) and is followed here as well. Z. lycetti is widespread in the Pliensbachian in Northwest Europe but was also recorded in Turkey and perhaps in North Africa.

\section{Zeilleria cf. subnumismalis (Davidson, 1851)}

(Figs 92-94)

* 1851 Terebratula numismalis, Lamarck var. subnumismalis - DAvidson, Oolitic and Liasic, p. 36, 38 , pl. V, fig. 10.

1869 Terebratula subnumismalis (Davidson). - Dumortier, Bassin du Rhône, p. 326, pl. XLI, figs 8-9 (? 10).

1878 Waldheimia sub-numismalis, Dav. - Davidson, Supplement, p. 62, pl. XXI, figs 1-7.

1885 Waldheimia (Zeilleria) subnumismalis, Dav. - PArona, Saltrio e Arzo, p. 257, pl. V, figs 8-14. 1893 Waldheimia subnumismalis, Dav. - PArona, Revisione Gozzano, p. 52, pl. I, fig. 26.

? 1926 Waldheimia subnumismalis Opp. - MoIsseIEV, Crimea, p. 980, pl. XXVIII, figs 34-36.

? 1934 Zeilleria subnumismalis Dav. E. Desl. - Moisseiev, Crimea and Caucasus, p. 131, 198, pl. XVII, figs 27-33.

1966 Zeilleria subnumismalis (Davidson, 1852) - SiBLík, Ramenon. Kostelec. bradla, p. 140, pl. II, fig. 1.

1974 Zeilleria (Zeilleria) subnumismalis (Davidson 1851) - DeLANCE, Zeilleridés, p. 202, pl. 3, figs $16,17$.

1990 Zeilleria (Zeilleria) subnumismalis (Davidson 1851) - Tсноumatchenco, Brach. jur. Kotel II, p. 24, text-fig. 14, pl. X, figs 6-11, pl. XI, figs 1-4.

2012 Zeilleria subnumismalis (Davidson 1851) - HöFlinger, Deutsch. Lias, p. 166 + fig. (unnumbered).

Material - Five partly incomplete specimens from Beytepe (Ankara area), probably Pliensbachian.

Measurements -

\begin{tabular}{lcccc}
\hline & L & W & T & Ch \\
\hline INV 2014.122. & 34.5 & 31.6 & 21.4 & - \\
\hline
\end{tabular}

Remarks - This species of Zeilleria was profusely and well illustrated by some classical authors (DAVIDSON 1878, 1.c.; PARONA 1885, 1.c.) and was exhaustively revised by DELANCE (1974). On this basis the identification of our specimens seems justified. Z. subnumismalis is a rather large, conservative form, with 
subcircular outline, moderate convexity and straight commissures. Some items of the above synonymy do not conform to these basic features, e.g. the specimen figured by Moisseiev (1926, l.c.) is too elongated; another item by MoIsSEIEV $(1934$, l.c.) is too small; their attribution to $Z$. subnumismalis is questionable. This is a Pliensbachian species of the NW-European region but it was recorded also from the Alpine-Carpathian region, the Balkans (Kotel), perhaps from the Crimea and now from Turkey.

\section{Zeilleria cf. mutabilis (Oppel, 1861)}

(Figs 95-97)

*1861 Terebratula mutabilis Opp. (Waldheimia.) - OppeL, Brachiopoden des unteren Lias, p. 538, pl. X, fig. 7.

v 2009 Zeilleria mutabilis (Oppel, 1861) - Vörös, Bakony, p. 183, text-figs 110, 111, pl. XXVIII, figs 5,6 (cum syn.).

v 2014 Zeilleria cf. mutabilis (Oppel, 1861) - Vörös, Yakacik, p. 244, pl. II, fig. 8.

Material - Five rather well-preserved specimens from Kösrelik Kızığ 1 (Ankara area), loose from Upper Sinemurian to Pliensbachian interval.

Measurements -

\begin{tabular}{lcccc}
\hline & L & W & T & Ch \\
\hline INV 2014.123. & 14.2 & 13.7 & 6.7 & - \\
\hline
\end{tabular}

Remarks - This species is one of the most frequently illustrated and best known Alpine Early Jurassic zeilleriid. Recently VöRös (2009) gave a detailed external and internal morphological description and discussion of $Z$. mutabilis. Externally, it is easy to recognize by its very simple but constant morphology (subpentagonal outline, moderately flat valves, straight commissures, erect to slightly incurved beak), and on the basis of these features, the identification of our specimens seems to be justified. Z. mutabilis is frequent in the Sinemurian and Pliensbachian of the Alpine-Mediterranean region, but occurs also in North Africa, the Balkans and Turkey; therefore, it tends to be cosmopolitan in distribution.

Genus Aulacothyris Douvillé, 1879

Aulacothyris resupinata (J. Sowerby, 1816)

(Figs 98-100)

* 1816 Terebratula resupinata. - J. Sowerby, Mineral Conchology II, p. 116, pl. CL, figs. 3, 4. 1851 Terebratula resupinata, Sow. - Davidson, Oolitic and Liasic, p. 31, pl. IV, figs 1-5. 1959 a Aulacothyris cf. A. resupinata (J. Sowerby) - AGER, Turkey, p. 1025, pl. 129, fig. 5.

1974 Aulacothyris resupinata (Sowerby 1816) - Delance, Zeilleridés, p. 317, pl. 6, figs 14-26.

1975 Aulacothyris resupinata (Sowerby 1818) - Comas-Rengifo \& GoY, Ribarredonda, p. 320, pl. 2, figs 5, 6 . 
1990 Aulacothyris resupinata (J. Sowerby, 1816) - Tсноumatchenco, Brach. jur. Kotel II, p. 35, text-figs 21, 22, pl. XI, figs 6-10.

2010 Aulacothyris resupinata (Sowerby, 1818) - Alméras et al., Massif Armoricain, p. 62, text-fig. 21. v 2014 Aulacothyris resupinata (J. Sowerby, 1816) - VöRös, Yakacik, p. 245, pl. II, fig. 10.

Material - One rather well-preserved specimen from Günüviran (Bilecik area), loose from Upper Sinemurian to Lower Pliensbachian interval.

\begin{tabular}{ccccc} 
Measurements - & \multicolumn{1}{c}{} \\
\hline & $\mathrm{L}$ & $\mathrm{W}$ & $\mathrm{T}$ & $\mathrm{Ch}$ \\
\hline INV 2014.124. & 11.3 & 10.3 & 4.9 & 2.7 \\
\hline
\end{tabular}

Remarks $-A$. resupinata is a frequently illustrated and well-known European zeilleriid species and it was thoroughly discussed by DELANCE (1974) and ALMÉRAS et al. (2010). On the basis of its elongated oval outline, erect beak with well-developed beak ridges and the shallow but long dorsal sulcus, starting very posteriorly, our specimen was easy to identify with this species. A. resupinata differs from $A$. anatolica (Vadász, 1913) by its narrower sulcus and by its oval outline, in contrast to the subpentagonal outline of $A$. anatolica, where the greatest width is near the anterior end of the shell. A. resupinata occurs frequently in the Pliensbachian of the NW-European region, but was recorded also in North Africa, the Balkans (Kotel) and Turkey; therefore, it tends to be cosmopolitan in distribution.

\section{Aulacothyris anatolica (Vadász, 1913)}

(Figs 101-103, 104-106)

v* 1913a Waldheimia anatolica nov. f. - VADÁsz, Kisázsia, p. 61, text-fig. 5.

v $1913 b$ Waldheimia anatolica nov. f. - VADÁsz, Kleinasien, p. 69, text-fig. 6.

? 1926 Waldheimia (Aulacothyris) salgirensis n. sp. - MoIsseiev, Crimea, p. 983, 993, pl. XXVIII, figs 40-42.

? 1934 Aulacothyris salgirensis Mois. - Moisseiev, Crimea and Caucasus, p. 153, 202, pl. XIX, figs 22-25.

1959 a Aulacothyris anatolica (Vadasz) - AgER, Turkey, p. 1025, pl. 129, fig. 1.

v 2014 Aulacothyris anatolica (Vadász, 1913) - Vörös, Yakacik, p. 245, text-fig. 3, pl. II, fig. 11.

Material - Seven moderately preserved specimens from Günüviran (Bilecik area), Kösrelik Kızığı (Ankara area) and Çalık (Gümüşhane area), loose from Upper Sinemurian to Pliensbachian interval.

\begin{tabular}{lcccc}
\multicolumn{2}{c}{ Measurements - } & \multicolumn{5}{c}{} \\
\hline & $\mathrm{L}$ & $\mathrm{W}$ & $\mathrm{T}$ & $\mathrm{Ch}$ \\
\hline INV 2014.125. & 14.3 & 12.9 & 8.8 & 6.5 \\
INV 2014.126. & 19.2 & 15.4 & 10.5 & 5.1 \\
\hline
\end{tabular}

Remarks - This typical species of the genus Aulacothyris was first described by VADÁsz $(1913 a, b)$ from Yakacik (Turkey), and a detailed revision of the same topotypical material was given recently by VöRös (2014), including the demon- 

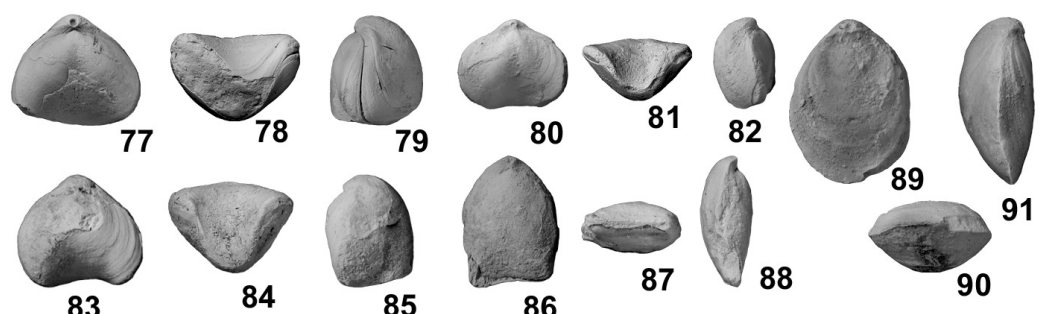

86

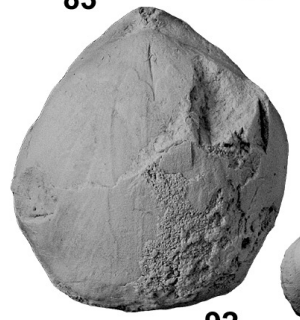

92

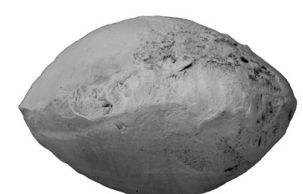

87
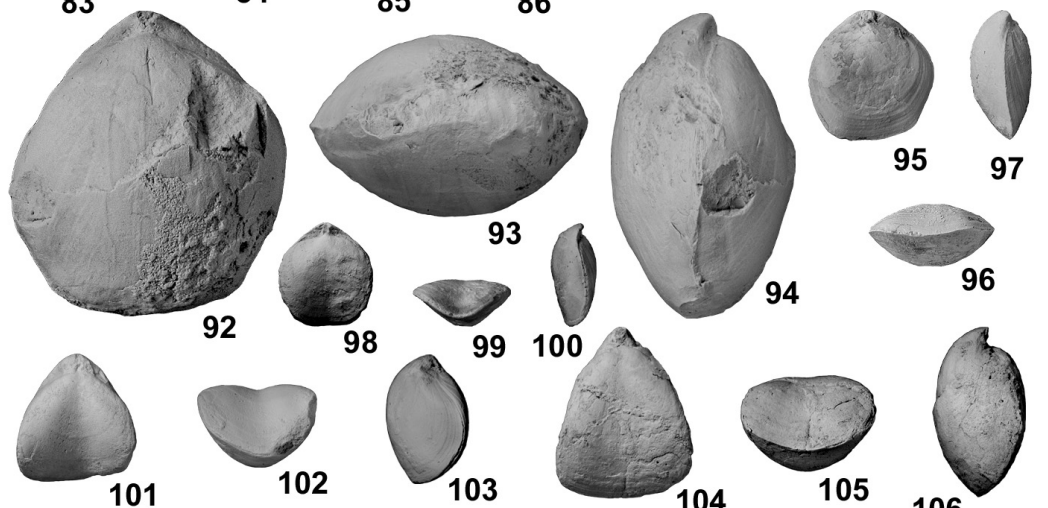

98

93
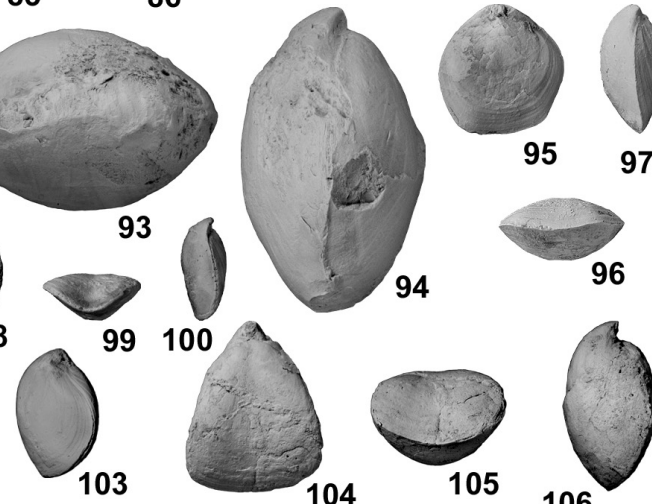

99100
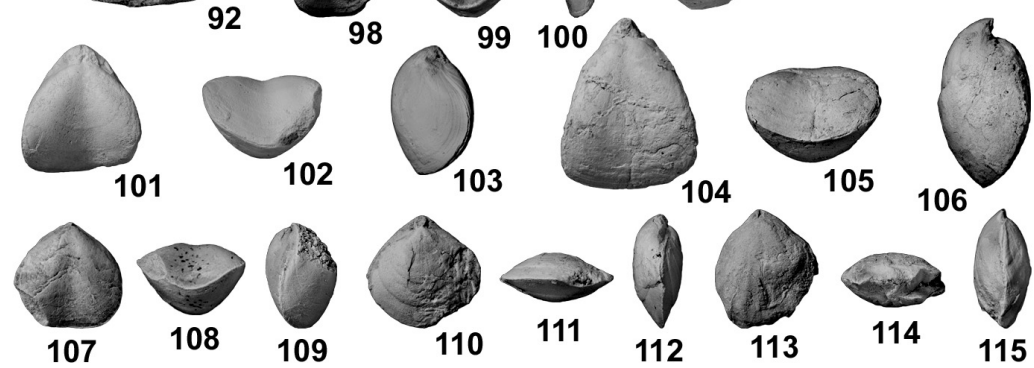

Figs 77-79. Linguithyris aspasia (Zittel, 1869), INV 2014.116., Günüviran, Sinemurian to Pliensbachian, $77=$ dorsal view, $78=$ anterior view, 79 = lateral view. - Figs 80-82. Linguithyris aspasia (Zittel, 1869), INV 2014.117., Günüviran, Sinemurian to Pliensbachian, $80=$ dorsal view, $81=$ anterior view, 82 = lateral view. - Figs 83-85. Linguithyris aspasia (Zittel, 1869), INV 2014.118., Hasanoğlan, Pliensbachian, 83 = dorsal view, $84=$ anterior view, $85=$ lateral view. - Figs 86-88. Zeilleria cf. waterhousi (Davidson, 1851), INV 2014.120., Çalık, Pliensbachian, $86=$ dorsal view, $87=$ anterior view, 88 = lateral view. - Figs 89-91. Zeilleria cf. lycetti (Davidson, 1851), INV 2014.121., Kösrelik Kızığı, Sinemurian to Pliensbachian, 89 = dorsal view, 90 = anterior view, $91=$ lateral view. - Figs 92-94. Zeilleria cf. subnumismalis (Davidson, 1851), INV 2014.122., Beytepe, Pliensbachian, 92 = dorsal view, 93 = anterior view, 94 = lateral view. - Figs 95-97. Zeilleria cf. mutabilis (Oppel, 1861), INV 2014.123., Kösrelik Kızığı, Sinemurian to Pliensbachian, 95 = dorsal view, 96 = anterior view, 97 = lateral view. - Figs 98-100. Aulacothyris resupinata (J. Sowerby, 1816), INV 2014.124., Günüviran, Sinemurian to Pliensbachian, 98 = dorsal view, 99 = anterior view, 100 = lateral view. - Figs 101-103. Aulacothyris anatolica (Vadász, 1913), INV 2014.125., Günüviran, Sinemurian to Pliensbachian, 101 = dorsal view, $102=$ anterior view, 103 = lateral view. - Figs 104-106. Aulacothyris anatolica (Vadász, 1913), INV 2014.126., Kösrelik Kızığı, Sinemurian to Pliensbachian, $104=$ dorsal view, $105=$ anterior view, 106 = lateral view. - Figs 107-109. Bakonyithyris cf. apenninica (Zittel, 1869), INV 2014.127., Alacaatl, Pliensbachian, 107 = dorsal view, 108 = anterior view, 109 = lateral view. - Figs 110-112. Cincta numismalis (Lamarck, 1819), INV 2014.128., Alacaatl, Pliensbachian, $110=$ dorsal view, $111=$ anterior view, 112 = lateral view. - Figs 113-1 15. Fimbriothyris cf. guerangeri (Deslongchamps, 1856), INV 2014.129., Yakacik, Pliensbachian, $113=$ dorsal view, $114=$ anterior view, $115=$ lateral view. (All figures are in natural size. Specimens have been coated with ammonium chloride before photography.) 
stration of the internal morphology of $A$. anatolica. It was also shown that $A$. salgirensis introduced by MoISSEIEv (1926), was very similar externally and probably conspecific with $A$. anatolica. This view was strongly supported by the serial sections of $A$. salgirensis published by AntoshtCHENKo (1970, fig. 4), which are particularly similar to those of $A$. anatolica. Our species differs from $A$. resupinata (J. Sowerby, 1816) by its broad and shallow sulcus and that its greatest width is attained near the anterior end of the shell. From this point of view, $A$. anatolica is somewhat similar to A.? ballinensis (Haas, 1912; see in Vörös 2009), but it is more elongated and its sulcus starts more posteriorly and is significantly deeper. $A$. anatolica was known only from Yakacik (Turkey), but in the light of the new data presented here, it seems to be widespread in other parts of northern Anatolia.

Genus Bakonyithyris Vörös, 1983

Bakonyithyris cf. apenninica (Zittel, 1869)

(Figs 107-109)

* 1869 Terebratula (Waldheimia) Apenninica. Zitt. - ZitTel, Central-Appenninen, p. 127, pl. XIV, fig. 9.

v 2009 Bakonyithyris apenninica (Zittel, 1869) - VöRös, Bakony, p. 198, text-figs 121-124, pl. XXIX, figs 5-8 (cum syn.).

Material - Two poorly preserved specimens from Alacaatlı (Ankara area), probably Pliensbachian.

\begin{tabular}{lcccc} 
Measurements - & \multicolumn{1}{c}{} \\
\hline \multicolumn{1}{c}{ L } & W & T & Ch \\
\hline INV 2014.127. & 11.4 & 11.7 & 7.5 & 3.2 \\
\hline
\end{tabular}

Remarks - This species is very closely related to B. pedemontana (Parona, 1893), the type species of Bakonyithyris and was recently revised and discussed in detail by Vörös (2009). One of our specimens, illustrated in figs. 107-109, is a typical representative of $B$. apenninica, whereas the anterior commissure of the other specimen tends to be somewhat trapezoidal and reminding in this respect to B. meneghinii (Parona, 1880). B. apenninica is a dominantly Pliensbachian species, typical for the Alpine-Mediterranean region but it was recorded also from North Africa and now from Turkey.

Genus Cincta Quenstedt, 1868

Cincta numismalis (Lamarck, 1819)

(Figs 110-112)

*1819 Terebratula numismalis. - LAMARCK, Histoire naturelle, p. 249, no. 17. 
1926 Waldheimia numismalis Lam. - Moisseiev, Crimea, p. 980, pl. XXVIII, figs 31-33.

v 2011 Cincta numismalis (Lamarck, 1819) - Vörös \& KANDEMIR, Eastern Pontides, p. 358, fig. 5/6 (cum syn.).

Material - One moderately preserved specimen from Alacaatlı (Ankara area), probably Pliensbachian.

Measurements -

\begin{tabular}{lcccc}
\hline & L & W & T & Ch \\
\hline INV 2014.128. & 12.1 & 12.4 & 5.1 & - \\
\hline
\end{tabular}

Remarks - This species has a very characteristic, flat, lenticular shape and a marked ventral umbo, bordered by sharp beak ridges. C. numismalis was discussed in details by Delance (1974) and Alméras \& Fauré (2000), who illustrated the rather wide morphological variability and cleared up its generic attribution. On this basis, the identification of our specimen, though it is rather small, seems to be confirmed. C. numismalis is a characteristic NW-European species, long-ranging from the late Sinemurian to the Pliensbachian. It was described and illustrated from the Balkans (Kotel) and Crimea and another localities of Turkey by AGER (1959a) and Vörös \& KANDEMIR (2011).

Genus Fimbriothyris Deslongchamps, 1884

Fimbriothyris cf. guerangeri (Deslongchamps, 1856)

(Figs 113-115)

1856 Terebratula (Waldheimia) guerangeri, E.-D. - Deslongchamps, Précigné, p. 304, pl. XVII, fig. 1.

1871 Terebratula Guerangeri - Quenstedt, Petrefactenkunde, p. 301, pl. 45, fig. 92.

1907 Waldheimia tranzensis n. f. - DAL PIAZ, Sospirolo, p. 62, text-fig. 4.

1942 Zeilleria Guerangeri E. Desl. sp. - DuBAR, Multiplissées, p. 51, text-fig. 15, pl. II, fig. 16.

1974 Fimbriothyris guerangeri (Deslongchamps 1856) - DelanCE, Zeilleridés, p. 279, pl. 6, figs $1-5$.

Material - One poorly preserved specimen from Yakacık, Pliensbachian.

Measurements -

\begin{tabular}{lcccc}
\hline & L & W & T & Ch \\
\hline INV 2014.129. & 13.4 & 11.7 & 6.1 & - \\
\hline
\end{tabular}

Remarks - Our specimen is rather poorly preserved, but by its oval outline, straight commissures, the beak characters, the presence of the median septum and first of all the radial multiplication render it the closest to F. guerangeri. The original figures by DeSLONGCHAMPS $(1856,1$.c.) portray a specimen with rather angular anterior part trapezoidal in outline and the illustration of "Waldheimia tranzensis" by DAL PIAZ (1907, 1.c.) also corresponds to this. Later authors 
(Dubar 1942; Delance 1974), on the basis of larger material, expanded the concept of this species and included forms with more oval outlines.

Similar forms, where, in contrast to the typical $F$. guerangeri, the marginal multiplication appeared only at the anterior margin, have been described and illustrated by Tсноumatchenco (1990, p. 33, pl. V, fig. 1, pl. VII, fig. 7) from Kotel as Fimbriothyris sp. indet., and by Vörös \& KANDEMIR (2011, p. 359, figs 5/7, 5/8) from the Eastern Pontides as Fimbriothyris sp., aff. guerangeri. These probably represent another, closely allied species of Fimbriothyris. F. gueranger i is a Pliensbachian species, rather cosmopolitan in geographical distribution, from the NW-European and the Mediterranean regions to Turkey.

\section{CONCLUSIONS}

The Early Jurassic brachiopods collected by Füsun Alkaya from diverse localities of northern Anatolia (Turkey) have been examined in detail. The taxonomic and nomenclatural study of the 93 specimens resulted in 32 brachiopod taxa. They represent 18 genera and 31 nominal species; these have been shortly described and documented by photographs and partly by serial sections. One species: Cirpa alkayae is introduced and described as new.

The brachiopods have been collected from 10 localities, from the Bilecik, the Ankara and the Gümüşhane areas. All localities fall to the Sakarya Zone of northern Anatolia, most of them are associated to the occurrences of the Karakaya Complex which was contiguous with the Taurian series of the Crimea (OKAY et al. 2006, p. 398).

A detailed palaeobiogeographical evaluation of this brachiopod fauna was beyond the scope of the present paper. Nevertheless, considering only the simple presence vs. absence data of the identified species in the major Tethyan palaeogeographic provinces (NW-European, vs. Mediterranean) we obtain the following numbers: besides 6 endemic and 3 cosmopolitan species, 11 species have NWEuropean, and 11 species have Mediterranean affinity. The preliminary conclusion is that the Early Jurassic brachiopod fauna of the Sakarya Zone has a transitional character between the two major faunal provinces. This is in accordance with the previous results from the eastern Pontides (Vörös \& KANDEMIR 2011, p. 351) and further emphasises the faunal similarity between Sakarya/Pontides and the Crimea.

Acknowledgements - The author is indebted to Hayriye Füsun Alkaya, who initiated the present study and provided the meticulously prepared brachiopod samples with the basic information on the localities. The useful advices by Miloš Siblík in certain taxonomic problems and by Arif 
Delikan about the locality Alacaatlı are greatly acknowledged. The brachiopod photographs have been taken by Mariann Bosnakoff. Thanks are due to Alfréd Dulai and José Baeza-Carratalá for carefully reviewing the manuscript.

\section{REFERENCES}

Ager D. V. 1954: The genus Gibbirhynchia in the British Domerian. - Proceedings of the Geologists' Association 65: 25-51.

AgER D. V. 1959a: Lower Jurassic brachiopods from Turkey. - Journal of Paleontology 33(6): 1018-1028.

Ager D. V. 1959b: A monograph of the British Liassic Rhynchonellidae. Part II. - Palaeontographical Society, London 112: 51-84.

Ager D. V. 1962: A monograph of the British Liassic Rhynchonellidae. Part III. - Palaeontographical Society, London 116: 85-136.

AgER D. V. 1983: Allopatric speciation - an example from the Mesozoic Brachiopoda. - Palaeontology 26(3): 555-565.

AgER D. V. 1991: Mesozoic brachiopod fauna from the Western Pontides, Turkey; their stratigraphical, palaeogeographical and palaeoecological significance. - Geologica Romana 27: 237-243.

Ager D. V., Gutnic M., Juteau T. \& Monod O. 1980: New Early Jurassic brachiopods from Southern Turkey. - Bulletin of the Mineral Research and Exploration Institute of Turkey 91(1978): 59-75.

Alkaya F. 1981: Liassic Ammonite Zones of the Bilecik Province. - Istanbul Yerbilimleri 2(3-4): 297-302. (in Turkish with English abstract)

Alkaya F. 1982: Taxonomic revision of the Lower Jurassic (Liassic) Phylloceratids of Northern Turkey (part I). - Türkiye Jeoloji Kurumu Bülteni 25: 31-40. (in Turkish with English abstract)

Alkaya F. 1983: Taxonomic revision of the Lower Jurassic (Liassic) Phylloceratids of Northern Turkey (part II). - Türkiye Jeoloji Kurumu Bülteni 26: 65-72. (in Turkish with English abstract)

Alkaya F. 1984: On the presence of Villania (Ammonoidea) in Turkey. - Bulletin of the Research and Exploration Institute of Turkey 97-98: 40-43.

AlKaYA F. 1991: Sinemurian-Lower Pliensbachian ammonite zones and taphonomy of the Hasanoğlan (Ankara) area. - In: Yetis C. (ed.): Ahmet Acar Geology Symposium, Proceedings, Çukurova University, Adana, pp. 11-21. (in Turkish with English abstract)

Alkaya F. \& Meister C. 1995: Liassic Ammonites from the central and eastern Pontides (Ankara and Kelkit areas, Turkey). - Revue de Paléobiologie 14(1): 125-193.

Alméras Y. 1964: Brachiopodes du Lias et du Dogger. - Documents des Laboratoires de Géologie de Lyon 5: 1-161.

AlmérAs Y., BÉCAud M. \& Cougnon M. 2010: Brachiopodes liasiques de la bordure sud du Massif Armoricain. - Bulletin de la Société des Sciences Naturelles de l'Ouest de la France, Nantes, h. s. 2010-1: 1-131.

Alméras Y. \& Cougnon M. 2013: Les Brachiopodes jurassiques (Spiriferida et Rhynchonellida). Principaux genres et leur évolution. Les espèces, extensions verticales et répartitions géographiques. - Documents des Laboratoires de Géologie, Lyon 170: 1-227.

Alméras Y. \& Fauré P. 2000: Les Brachiopodes Liasiques des Pyrénées. Paléontologie, biostratigraphie, paléobiogeographie et paléoenvironnements. - Strata, Sér. 2, 36: 1-395.

Alméras Y. \& Fauré P. 2013: Brachiopodes du Lias et de l'Aalenien du Quercy. - Strata, Sér. 2, 47: 1-104.

Altiner D., Koçyiğit A., Farinacci A., Nicosia U. \& Conti M. A. 1991: Jurassic-Lower Creataceous stratigraphy and paleogeographic evolution of the southern part of NorthWestern Anatolia (Turkey). - Geologica Romana 27: 13-80. 
Antoshtchenko Z. A. 1970: On the phylogenetic connections of the genera Aulacothyris and Keratothyris (Brachiopoda). - Paleontologicheskii Zhurnal 1970(1): 73-81. (in Russian)

Arkell W. J. 1956: Jurassic Geology of the World. - Oliver and Boyd, Edinburgh, London, 806 pp.

BAEZA-CARRATALÁ J. F. 2013: Diversity patterns of Early Jurassic brachiopod assemblages from the westernmost Tethys (Eastern Subbetic). - Palaeogeography, Palaeoclimatology, Palaeoecology 381-382: 76-91. http://dx.doi.org/10.1016/j.palaeo.2013.04.017

BILGÜTAY U. 1960: Geology of the Hasanoğlan-Ankara region. - Maden Tetkik ve Arama Enstitüsü Dergisi, Foreign edition 54: 44-51.

Böскн J. 1874: Die geologischen Verhältnisse des südlichen Theiles des Bakony, II. - Mittheilungen aus dem Jahrbuche der königlichen ungarischen geologischen Anstalt 3(1): 1-180.

Böse E. \& SCHLosser M. 1900: Über die mittelliassische Brachiopodenfauna von Südtirol. Palaeontographica 46: 175-212.

BREMER H. 1965: Zur Ammonitenfauna und Stratigraphie des unteren Lias (Sinemurium bis Carixium) in der Umgebung von Ankara (Türkei). - Neues Jahrbuch für Geologie und Paläontologie, Abhandlungen 122(2): 127-221.

BUCH L. voN 1837: Über Delthyris oder Spirifer und Orthis. - Berlin, 79 pp.

BUCKMAN S. S. 1904: Jurassic Brachiopoda. - Annals and Magazine of Natural History 14(7): 389-397.

Carter J. L. \& Johnson J. G. 2006: Spiriferinida. - In: Kaesler R. L. (ed.): Treatise on Invertebrate Palaeontology. Part H, Brachiopoda (Revised), Volume 5, Rhynchonelliformea (part). - Geological Society of America and University of Kansas, Boulder, Colorado and Lawrence, Kansas, pp. 1877-1890.

Comas-Rengifo M. J. \& Goy A. 1975: Estratigrafía y paleontología del Jurásico de Ribarredonda (Guadalajara). - Estudios Geologicos 31: 297-339.

Dal Piaz G. 1907: Sulla fauna liasica delle tranze di Sospirolo. - Mémoires de la Société Paléontologique Suisse 33(1906): 1-64.

Davidson T. 1851-52: A Monograph of the British Fossil Brachiopoda, Vol. I: Part III: The Oolitic and Liasic Brachiopoda. - Palaeontographical Society, pp. 1-64, pls 1-13 (1851); pp. 65-100, pls 14-18 (1852), London.

Davidson T. 1876-78: A Monograph of the British Fossil Brachiopoda, Vol. IV: Part II: Supplement to the Jurassic and Triassic species. - Palaeontographical Society, pp. 73-144, pls 9-16 (1876); pp. 145-242, pls 17-21 (1878), London.

DelanCe J.-H. 1974: Zeilleridés du Lias d'Europe Occidentale. - Mémoires Géologiques de l'Université de Dijon 2: 1-406.

Deli A. \& ORHAN H. 2007: Stratigraphy of Jurassic-Cretaceous aged deposits outcropping around Alacaatli-Beytepe village (South West Ankara). - Journal of Selcuk University Faculty of Engineering and Architecture 22(4): 61-80. (in Turkish with English abstract)

Deslongchamps E. E. 1856: Note sur deux nouvelles térébratules du Lias moyen de Précigné (Sarthe). - Mémoires de la Société Linnéenne de Normandie 10: 302-305.

Di Stefano G. 1891: Il Lias medio del M. San Giuliano (Erice) presso Trapani. - Atti della Accademia Gioenia di Scienze Naturali in Catania 3: 121-270.

DubAR G. 1942: Études paléontologiques sur le Lias du Maroc. Brachiopodes, térébratules et zeilléries multiplissées. - Notes et Mémoires du Service Géologique du Maroc 57: 1-103.

Dulai A. 1992: The Early Sinemurian (Jurassic) brachiopod fauna of the Lókút Hill (Bakony Mts., Hungary). - Fragmenta Mineralogica et Palaeontologica 15: 41-94.

Dulai A. 2003: A Dunántúli-középhegység hettangi és kora-szinemuri (kora-jura) brachiopoda faunája II. Rendszertani leírások. (Hettangian and Early Sinemurian (Early Jurassic) brachiopods of the Transdanubian Central Range (Hungary) II. Systematic descriptions). - $A$ Bakony természettudományi kutatásának eredményei 27: 1-144. (In Hungarian) 
Dumortier E. 1869: Études paléontologiques sur les dépôts jurassiques du Bassin du Rhône. III. Lias moyen. - F. Savy, Paris, 348 pp.

Fucini A. 1895: Fauna dei calcari bianchi ceroidi con Phylloceras cylindricum Sow. sp. del Monte Pisano. - Atti della Societá Toscana di Scienze e Naturali, Memorie 14: 125-351.

Gemmellaro G. G. 1874: Sopra alcune faune giuresi e liasiche di Sicilia. Studi paleontologici. III: Sopra i fossili della zona con Terebratula Aspasia Menegh. della provincia di Palermo e di Trapani. - Giornale di Scienze Naturali ed Economiche, Palermo 10: 53-112.

GeYer G. 1889: Über die liassischen Brachiopoden des Hierlatz bei Halstatt. - Abhandlungen der kaiserlich-königlichen geologischen Reichsanstalt 15: 1-88.

HAAS H. 1884: Beiträge zur Kenntniss der liasischen Brachiopodenfauna von Südtyrol und Venetien. - Kiel, 32 pp.

Höflinger J. 2012: Die Brachiopoden des deutschen Lias. - Röthenbach, 206 pp.

ICZN 1999: International Code of Zoological Nomenclature. - The International Trust for Zoological Nomenclature, London, 306 pp.

LAMARCK A. DE 1819: Histoire naturelle des animaux sans vertèbres, vol. 6, part 1, Paris, 343 pp.

Lee D. E., MacKinnon D. I., Smirnova T. N., Baker P. G., Jin YU-Gan \& Sun Dong-Li 2006: Terebratulida. - In: KAesler R. L. (ed.): Treatise on Invertebrate Palaeontology. Part H, Brachiopoda (Revised), Volume 5, Rhynchonelliformea (part). - Geological Society of America and University of Kansas, Boulder, Colorado and Lawrence, Kansas, pp. 1965-2251.

Moisseiev A. S. 1926: Sur la faune des calcaires jurassiques inférieurs de la Crimée. - Izvestiya Geologicheskogo Komiteta (Bulletins du Comité Géologique), Leningrad, 44(1925)(10): 961-993.

Moisseiev A. S. 1934: The Jurassic Brachiopoda of the Crimea and the Caucasus. - Trudy Vsesoiuznyi Geologo-Razvedochnyi Obedineniya SSSR 203: 1-213. (in Russian with English summary)

Nutsubidze K. S. 1949: Liassic brachiopods from the region of the Dzirula Massif. - Trudy Geologicheskogo Instituta, Akademia Nauk Gruzinskoy SSR, Seriya Geologiya 5: 1-53. (in Georgian with Russian abstract)

OKan Y. \& HoşGör İ. 2007: The Bivalvia and Gastropoda fauna of the Ammonitico Rosso facies of Late Sinemurian-Early Pliensbachian of the Kösrelik Region (NE Ankara-Turkey); First record of annelid polychaete species and their paleogeographic and paleoecologic characteristics. - Bulletin of the Mineral Research and Exploration, Foreign Edition 135: 19-29.

OкаY A. I. 2008: Geology of Turkey: A synopsis. - Anschnitt 21: 19-42.

Okay A. I., Satir M. \& Siebel W. 2006: Pre-Alpide Palaeozoic and Mesozoic orogenic events in the Eastern Mediterranean region. - In: GeE D. G. \& STEPHENSON R. A. (eds): European Lithosphere Dynamics. - Geological Society, London, Memoirs 32: 389-405.

Oppel A. 1861: Über die Brachiopoden des unteren Lias. - Zeitschrift des deutschen geologischen Gesellschaft 13(4): 529-550.

Otкun G. 1942: Étude paléontologique de quelques gisements du Lias d'Anatolie. - Publications de l'Institut d'Études et de Recherches Minières de Turquie (B), Mémoires 8: 1-41.

Parona C. F. 1885: I Brachiopodi liassici di Saltrio e Arzo nelle Prealpi Lombarde. - Memorie del Reale Istituto Lombardo di Scienze e Lettere, Classe di scienze matematiche e naturali, Ser. 3, 15: 227-262.

Parona C. F. 1893: Revisione della fauna liassica di Gozzano in Piemonte. - Memorie della Reale Accademia delle Scienze di Torino, Ser. 2, 43: 1-62.

Quenstedt F. A. 1856-1858: Der Jura. (1856: pp. 1-576; 1857: pp. 577-823; 1858: pp. 824-842) - Laupp, Tübingen, 842 pp.

Quenstedt F. A. 1868-1871: Petrefactenkunde Deutschlands. II. Brachiopoden. - Fues's, Leipzig, 748 pp.

RAU K. 1905: Die Brachiopoden des mittleren Lias Schwabens, mit Ausschluss der Spiriferinen. Geologische und Palaeontologische Abhandlungen 10(N. F. 6)(5): 263-355. 
Roth Pletz A. 1886: Geologische-palaeontologische Monographie der Vilser-Alpen, mit besonderer Berücksichtigung der Brachiopoden-Systematik. - Palaeontographica 33: 1-180.

Rousselle L. 1977: Spiriférines du Lias moyen et supérieur au Maroc (Rides Prérifaines; Moyen Atlas) et en Espagne (Chaine Celtibérique orientale). - Notes et Mémoires du Service Géologique du Maroc 38: 153-175.

Savage N. M., Manceñido M. O., Owen E. F., Carlson S. J., Grant R. E., Dagys A. S. \& Sun DONG-Li 2002: Rhynchonellida. - In: KAESLER R. L. (ed.): Treatise on Invertebrate Palaeontology. Part H, Brachiopoda (Revised), Volume 4, Rhynchonelliformea (part). Geological Society of America and University of Kansas, Boulder, Colorado and Lawrence, Kansas, pp. 1027-1376.

SiBLíK M. 1964: K nálezu liasových brachiopodu v horni casti Belanské doliny. (Liassic brachiopods from the upper part of the Bela Valley (Belanska dolina) in the Velká Fatra Mts). - Geologické Práce, Zprávy 31: 157-181.

SibLík M. 1966: Ramenonoci Kosteleckého bradla. (The brachiopods of the Kostelec-Klippe). Geologické Práce, Zprávy 38: 137-157.

SibLí́ M. 1967a: Tetrarhynchiinae a Cyclothyridinae slovenského domeru. (Tetrarhynchiinae and Cyclothyridinae of Slovakia). - Geologické Práce, Zprávy 41: 11-25.

SiвLík M. 1967b: New species of Domerian rhynchonelloids from Slovakia. - Geologický Sborník 18(1): 151-168.

SiBLÍ K M. 1993: Lower Liassic Brachiopods from Steinplatte-Kammerköhralm Area near Waidring (Northern Calcareous Alps, Salzburg). - Jahrbuch der geologischen Bundesanstalt 136(4): 965-982.

SibLík M. 1999: New data on the Hettangian brachiopod fauna of the Northern Calcareous Alps (Austria, Bavaria). - Abhandlungen der Geologischen Bundesanstalt 56(2): 419-438.

SibLí́ M. 2008: A Jurassic brachiopod fauna from the Mitterwand area near Hallstatt (Upper Austria). - Jahrbuch der Geologischen Bundesanstalt 148(1): 59-87.

Sowerby J. 1812-1815: The Mineral Conchology of Great Britain. I. - London, 234 pp.

Sowerby J. 1815-1818: The Mineral Conchology of Great Britain. II. - London, 251 pp.

Sučić-Protić Z. 1969: Middle Liassic Brachiopoda of the Yugoslav Carpatho-Balkanids (Part I). - In: Mesozoic Brachiopoda of Yugoslavia. University of Belgrade, Monographs 1: 1-214.

Sučić-Protić Z. 1971: Middle Liassic Brachiopoda of the Yugoslav Carpatho-Balkanids (Part II). - In: Mesozoic Brachiopoda of Yugoslavia. University of Belgrade, Monographs 5: 1-150.

SuEss E. 1854: Über die Brachiopoden der Kössener Schichten. - Denkschriften der kaiserlichen Akademie der Wissenschaften, Mathematisch-naturwissenschaftliche Classe 7(2): 29-65.

Tсноumatchenco P. V. 1989: Brachiopodes des olistolithes jurassiques inférieurs et moyens inclus dans la Formation de Kotel - Jurassique moyen (Stara Planina orientale, Bulgarie). I. Rhynchonellida. - Palaeontology, Stratigraphy and Lithology 27: 3-30.

TChoumatchenco P. V. 1990: Brachiopodes des olistolithes jurassiques inférieurs et moyens inclus dans la Formation de Kotel (Jurassique moyen) (Stara Planina orientale, Bulgarie). II. Spiriferida, Terebratulida. - Palaeontology, Stratigraphy and Lithology 28: 3-40.

Tchoumatchenco P. V. 1994: Brachiopodes du Jurassique inférieur et moyen du Kef Sidi Amar - Massif Culminant de l'Ouarsenis (Algérie du Nord). - Geologica Balcanica 24(1): 25-61.

TomašovýcH A. 2006: A new Early Jurassic rhynchonellid brachiopod from the western Tethys and implications for systematics of rhynchonellids from the Triassic-Jurassic boundary. Journal of Paleontology 80(2): 212-228.

Uhlig V. 1880: Über die liassischen Brachiopodenfauna von Sospirolo bei Belluno. - Sitzungsberichte der mathematisch-naturwissenschaftlichen Classe der kaiserlichen Akademie der Wissenschaften 80(1879), Abt. 1:259-310. 
VADÁsz M. E. 1913a: Liászkövületek Kisázsiából. - Magyar Királyi Földtani Intézet Évkönyve 21(3): 51-72. (in Hungarian)

VADÁsz M. E. 1913b: Liasfossilien aus Kleinasien. - Mitteilungen aus dem Jabrbuche der königlichen ungarischen geologischen Reichsanstalt 21(3): 59-82.

VADÁsz E. 1918: Über das Vorkommen von Posidonomya alpina-Schichten in Anatolien. - Centralblatt für Mineralogie, Geologie und Paläontologie 13-14: 215-219.

Vörös A. 2009: The Pliensbachian brachiopods of the Bakony Mountains (Hungary). - Geologica Hungarica, Series Palaeontologica 58: 1-300.

Vörös A. 2014: A revision of the historical brachiopod collection from the Lower Jurassic of Yakacik (Ankara, Turkey), housed in the Geological and Geophysical Institute of Hungary. Földtani Közlöny 144(3): 231-254.

Vörös A. \& KANDEMIR R. 2011: A new Early Jurassic brachiopod fauna from the Eastern Pontides (Turkey). - Neues Jabrbuch für Geologie und Paläontologie, Abhandlungen 260: 343-363. http://dx.doi.org/10.1127/0077-7749/2011/0146

Vörös A., Szabó J., Dulai A., Szente I., Ebli O. \& Lobitzer H. 2003: Early Jurassic fauna and facies of the Schafberg area (Salzkammergut, Austria). - Fragmenta Palaeontologica Hungarica 21: 51-82.

ZItTEL K. A. 1869: Geologische Beobachtungen aus den Central-Appenninen. - Benecke's Geognostisch-Paläontologische Beiträge 2(2): 91-177. 